\title{
ToOthless IN TRUth? The Ethereal Rational Basis Test and the Prison Litigation ReForm Act's DisParate RESTRICTIONS ON AtTORNEY's FEES
}

\author{
Lynn S. Branham $\dagger$
}

Plaintiffs who prevail in certain civil rights actions, including those brought against state and local officials, can recover their "reasonable" attorney's fees under 42 U.S.C. $\$ 1988$. In calculating the fee award, courts typically apply the prevailing market rate for the attorney's services, multiplying that rate times the number of hours the attorney "reasonably expended" on the case. The Prison Litigation Reform Act (PLRA), enacted in 1996, substantially reduced the attorney's fees that prisoners can recover under $\$ 1988$ in lawsuits brought to vindicate their constitutional or other civil rights. The PLRA places a cap, currently $\$ 112.50$, on the hourly rate at which attorneys representing prisoners can be reimbursed through the fee award. In addition, the PLRA limits the fee award in cases in which a prisoner recovered monetary relief to $150 \%$ of the monetary judgment. This latter limitation will, in particular, result in minuscule fee awards in many civil rights cases brought by prisoners.

The differential treatment of prisoners under $\$ 1988$ tests the boundaries of equal protection. Four governmental interests, extrapolated from the PLRA's legislative history, might be invoked to defend the fee restrictions' constitutionality. This Article examines the interests purportedly undergirding the restrictions, concluding that the interests are either not legitimate or, in any event, do not support the distinction drawn between prisoners who bring meritorious civil rights claims and nonprisoners who bring such claims. If the question of the constitutionality of these restrictions were to come before the Supreme Court, the Court's decision would

Copyright (C) 2001 Califomia Law Review, Inc. Califomia Law Review, Inc. (CLR) is a Califomia nonprofit corporation. CLR and the authors are solely responsible for the content of their publications. $\dagger$ Visiting Professor, University of Illinois College of Law; B.A. 1976, University of Illinois; J.D., 1980, University of Chicago Law School. I would like to extend my thanks to my colleagues, Professors Kit Kinports, Andrew Leipold, David Meyer, and John Nowak, for providing me with their comments on an earlier draft of this article. 
reveal whether the rational basis test is, in truth, "toothless," despite the Court's protestations to the contrary.

\section{INTRODUCTION}

On August 9, 1997, police officers arrested Abner Louima, an immigrant from Haiti, after a fight erupted at a night club in New York City. ${ }^{1}$ At the police station, two of the officers took Louima into a bathroom where they punched and kicked him. ${ }^{2}$ One of the police officers then took a broomstick he had broken and shoved it into Louima's rectum. ${ }^{3}$ The officer next waved the stick, which was covered with feces, in front of Louima's mouth. ${ }^{4}$ The two police officers then removed Louima, his pants still pulled down, from the bathroom. ${ }^{5}$

Paramedics rushed Louima to the hospital, where his condition was described as critical. ${ }^{6}$ Louima suffered a tom lower intestine, a punctured bladder, and head injuries. ${ }^{7}$ For six months after he was sodomized, Louima had to use a colostomy bag to relieve intestinal blockage. ${ }^{8}$

In a civil rights suit brought under 42 U.S.C. $\$ 1983$ to recover compensatory and punitive damages for the police officers' violation of his constitutional rights, ${ }^{9}$ the attorney's fees that a court could award Louima under 42 U.S.C. $\S 1988^{10}$ would vary dramatically depending on one factwhether Louima was confined in a jail, prison, or other correctional facility at the time he filed the lawsuit." "If Louima was so confined, the fee award could compensate his attorneys at a rate no higher than \$I I2.50 an hour for their time spent litigating the civil rights suit due to restrictions imposed by

1. United States v. Bruder, 103 F. Supp. 2d 155, 159 (E.D.N.Y. 2000).

2. Id. at $162-63$.

3. Id. at 163 .

4. Id.

5. Id. at 164 .

6. Susan Ferraro, Haunted by Memories Psyche's Scars Last to Heal, N.Y. Dally News, Aug. 25,1997 , at 6 .

7. Bruder, 103 F. Supp. 2d at 165.

8. Id.

9. Individuals whose constitutional or other federal rights were violated by state or local officials can seek remedial relief under Section 1983. 42 U.S.C. $\$ 1983$ (1994).

10. 42 U.S.C. $\$ 1988(b)$ provides in pertinent part as follows:

In any action or proceeding to enforce a provision of sections 1977, 1977 A, 1978, 1979, 1980 , and 1981 of the Revised Statutes [42 U.S.C. $\$ \S 1981-1983,1985,1986$ ], title IX of Public Law 92-318 [20 U.S.C. $\$ 1681$ et seq.], the Religious Freedom Restoration Act of 1993, the Religious Land Use and Institutionalized Persons Act of 2000, title VI of the Civil Rights Act of 1964 [42 U.S.C. $\$ 2000$ d et seq.], or section 40302 of the Violence Against Women Aet of 1994, the court, in its discretion, may allow the prevailing party, other than the United States, a reasonable attorney's fee as part of the costs .... 42 U.S.C. $\$ 1988(b)$ (1994).

11. See 42 U.S.C. $\S 1997 \mathrm{e}$ (d)(3) (Supp. IV 1999); see also text accompanying notes 53-62. 
the Prison Litigation Reform Act (PLRA). ${ }^{12}$ On the other hand, if Louima was not confined in a correctional facility when he filed the civil rights suit, the court would base the fee award on the prevailing market rate for the attorneys' services. ${ }^{13}$ Thus, if Louima was never confined in a jail or prison or waited until his release from confinement before bringing the lawsuit, he could receive perhaps two to three times more in attorney's fees for the work expended vindicating his constitutional rights. ${ }^{14}$

A second case involving the use of excessive force illustrates another limitation on the attorney's fees recoverable by prisoners, a limitation to which nonprisoners are not subject. In 1992, three correctional officers beat up Cecil Lucas, an inmate on death row in South Carolina. ${ }^{15}$ With Lucas in handcuffs and leg irons, the officers punched him in the face, struck his face against the cell bars, and threw him, face first, onto the cement floor. ${ }^{16}$ Lucas's face was bruised and swollen from this beating. ${ }^{17}$

Lucas later filed a $\S 1983$ suit against the three correctional officers who beat him. ${ }^{18}$ After a four-day trial, a jury returned a verdict for Lucas against all three defendants but awarded him only ten cents im damages. ${ }^{19}$ The presiding judge found that the low damages award stemmed, in part, from the jury's natural reluctance to award damages to a prisoner on death row. ${ }^{20}$ In light of what the court termed the "very unique" and difficult circumstances of this case, ${ }^{21}$ the court described the verdict for Lucas as a "significant accomplishment" for his attorneys. ${ }^{22}$ In addition, the court noted that Lucas's attorneys had had to expend a significant amount of

12. Pub. L. No. 104-134, 110 Stat. 1321-66 (1996) (codified as amended at 18 U.S.C. $\$ \$ 3624(b)$ (Supp. 2000), 3626 (Supp. 2000) and in scattered sections of 28 and 42 U.S.C.). See infra text accompanying notes 53-60.

13. See infra text accompanying note 96 .

14. See, e.g., Madrid v. Gomez, 190 F. 3d 990, 993 n.2 (9th Cir. 1999) (holding that two prisoners' attorneys compensated at the rate of $\$ 305$ and $\$ 290$ an hour for their work in a conditions-ofconfinement case before the enactment of the PLRA could now only be compensated at the rate of $\$ 112.50$ an hour).

15. Lucas v. Guyton, 901 F. Supp. $1047,1050-51$ (D.S.C. 1995).

16. Id. at 1051 .

17. Id.

18. Id. at 1050 .

19. Id. at 1051 .

20. Id. at 1054 n.5 ("[M]ost jurors would find it difficult to award monetary damages to a death row inmate."). The court also noted that the jury might have awarded Lucas only nominal damages because he did not prove that he had sustained any monetary losses, such as medical bills, from his injuries. $I d$.

21. See id. at $\mathbf{1 0 5 2}$ ("It is hard to imagine a more repugnant or unsympathetic client to put before a jury."). In addition to facing the challenges of representing such an unsavory character, Lucas's attorneys were forced to present the testimony of his witnesses by deposition, while the defendants' witnesses, fellow correctional officers, testified in person before the jury. Id. at 1057. All of the plaintiff's witnesses were death row inmates, further compounding the difficulty of winning the credibility contest before the jury. Id.

22. Id. at 1052 . 
time litigating the case, over 171 hours, ${ }^{23}$ because the defendants had refused to participate in settlement negotiations. ${ }^{24}$ The court then awarded Lucas $\$ 28,712.50$ in attorney's fees. ${ }^{25}$

If Lucas had suffered the same beating resulting in the same injuries today, the attorney's fees he could recover from the defendants would be paltry in comparison. Because the PLRA requires the attorney's fees paid by defendants to prisoners under $\S 1988$ to be capped at $150 \%$ of a monetary judgment, ${ }^{26}$ a court today could require the defendants to pay Lucas, at most, fifteen cents in attorney's fees.

This Article analyzes the constitutionality of two restrictions the PLRA places on the attorney's fees prisoners can recover under 42 U.S.C. $\S 1988$ : the hourly-rate limitation and the cap based on the size of a monetary judgment. ${ }^{27}$ Part I begins with an overview of the PLRA, including its restrictions on attorney's fees. Part II examines the rules that govern the award of attorney's fees under $\S 1988$, highlighting the key distinctions between the fees awarded nonprisoners and those awarded prisoners.

Part III then analyzes whether the differential treatment of prisoners and nonprisoners when awarding attorney's fees under $\S 1988$ violates equal protection. This Part of the Article starts with an analysis of whether prisoners and nonprisoners are, in this context, similarly situated for equal protection purposes. After identifying the appropriate equal protection test to apply to the PLRA's fee restrictions, Part III then proceeds to scrutinize four governmental interests to determine if they validate the fee restrictions' discrepant treatment of prisoners.

Part IV follows with a discussion of the practical impact of the PLRA's fee restrictions. Through its exposition of four hypothetical cases contrasting the attorney's fees recoverable by prisoners and nonprisoners under $\S 1988$, this Part of the Article highlights the capriciousness of the line drawn between prisoners and nonprisoners by the PLRA's fee restrictions. Part $\mathrm{V}$ then sets forth a framework for a congressional policy analysis of the recovery of attorney's fees under $\S 1988$.

23. Id. at 1059. A paralegal also worked over sixty-three hours on the case, and law clerks and other assistants devoted over twelve hours to the case. Id.

24. Id.

25. Id. at 1060 .

26. 42 U.S.C. $\$ 1997 \mathrm{e}(\mathrm{d})(2)$ (Supp. IV 1999).

27. The courts are currently divided on the constitutionality of these two fee restrictions. Compare, e.g., Boivin v. Black, 225 F.3d 36, 46 (1st Cir. 2000) (holding that the 150\% cap is constitutional), with Walker v. Bain, 65 F. Supp. 2d 591, 605 (E.D. Mich. 1999) (holding that the $150 \%$ cap violates equal protection); compare Hadix v. Johnson, 230 F.3d 840, 847 (6th Cir. 2000) (holding that the hourly-rate restriction does not violate equal protection), and Madrid v. Gomez, 190 F.3d 990, 996 (9th Cir. 1999) (same), with Johnson v. Daley, 117 F. Supp. 2d 889, 892-93 (W.D. Wis. 2000) (holding that the hourly-rate restriction is unconstitutional). The Third Circuit is divided equally on the constitutionality of the $150 \%$ fee cap. See Collins v. Montgomery County Bd. of Prison Inspectors, 176 F.3d 679, 686 (3d Cir. 1999) (en banc), cert. denied, 528 U.S. 1115 (2000). 


\section{The Prison Litigation Reform Act}

\section{A. Key Provisions}

The Prison Litigation Reform Act was enacted in $1996 .{ }^{28}$ The Act had two ostensible purposes: to curb the filing of frivolous lawsuits by prison$\operatorname{ers}^{29}$ and to end what was considered judicial micromanageinent of federal, state, and local correctional facilities. ${ }^{30}$

The PLRA includes a number of provisions to meet its first objective of curbing frivolous lawsuits. First, prisoners must seek redress through a prison's grievance process before filing a lawsuit under 42 U.S.C. $\S 1983$ or any other "[f]ederal law" contesting the conditions of their confinement. ${ }^{31}$ Second, all prisoners must pay the full filing fee when bringing a lawsuit or appeal in federal court, ${ }^{32}$ although indigent prisoners inay pay the fee in installments. ${ }^{33}$ Third, the PLRA directs courts to dismiss sua sponte prisoners' frivolous claims, as well as those that are malicious, fail to state a claim upon which relief can be granted, or seek damages from a defendant immune from monetary relief. ${ }^{34}$

Fourth, the PLRA bars prisoners from obtaining recoinpense for mental or emotional injuries suffered while in custody unless those injuries

28. See supra note 12.

29. 141 CoNG. REC. SI4,413 (1995) (statement of Senator Dole in introducing S. 1279, "The Prison Litigation Reform Act of 1995") (stating that the PLRA responds to "the alarming explosion in the number of frivolous lawsuits filed by State and Federal prisoners").

30. Id. at S14,414 (stating that the PLRA will "restrain liberal Federal judges ... who have used these complaints to inicromanage State and local prison systems"); see also H.R. REP. No. 104-21, at 7-9 (1995) (discussing the purposes of the PLRA's precursors, the "Stopping Abusive Prisoner Lawsuits Act" and the "Stop Turning Out Prisoners Act").

31. 42 U.S.C. $\$ 1997$ e(a) (Supp. IV 1999).

32. 28 U.S.C. $\$ 1915(\mathrm{~b})(1)(2000)$.

33. Id. Prisoners who cannot pay the full filing fee in advance must generally still pay an initial partial filing fee. Id. This initial fee is calculated by taking twenty percent of the greater of the following: the average monthly deposits to the prisoner's trust-fund account at the prison or the average monthly balance in that account during the six months preceding the filing of the lawsuit or appeal. Id. $\$ 1915$ (b)(I)(A)-(B). Prisoners who do not currently have the mcans to pay this initial fee can still bring their suit or appeal, id. $\S 1915$ (b)(4), but money subsequently deposited in their account will be withdrawn to pay this fee. See Hatchet v. Nettles, 201 F.3d 651, 653 (5th Cir. 2000); McGore v. Wrigglesworth, 114 F.3d 601, 606 (6th Cir. 1997).

After paying the initial partial fee, prisoners must make monthly installment payments equaling twenty percent of the income credited to the trust-fund account the month before until the full filing fee is paid. 28 U.S.C. $\$ 1915$ (b)(2). Prison officials, however, can only withdraw sums due from the account when the total amount of money in the account exceeds ten dollars. Id.

34. The PLRA contains three overlapping provisions directing courts to screen prisoners' complaints and dismiss those claims that are frivolous, malicious, fail to state a claim for which relief can be granted, or seek monetary relief from a defendant with imınunity from damages liability. 28 U.S.C. $\$ 1915(\mathrm{e})(2)$ applies to prisoners, as well as nonprisoners, proceeding in forma pauperis in the district court or on appeal. McGore, 114 F.3d at 60 S. 28 U.S.C. $\$ 1915$ A(b) applies to prisoners' lawsuits brought against a governmental entity or official. Id. Finally, 42 U.S.C. $\S 1997$ e(c) applies to cases in which prisoners are contesting the legality of the conditions of their confinement under 42 U.S.C. $\$ 1983$ or some other "[f]ederal law." 
were accompanied by some form of "physical injury." ${ }^{35}$ And fifth, indigent prisoners who have previously filed three or more civil actions or appeals while they were incarcerated that were dismissed for frivolousness, maliciousness, or failure to state a claim must, as a general rule, prepay the full filing fee before a court will adjudicate their claims. ${ }^{36}$ Only if a prisoner is facing an "imminent" threat of "serious physical injury" can a court grant a prisoner with three such dismissals leave to proceed in forma pauperis. ${ }^{37}$

To meet the PLRA's second objective of curtailing perceived federal court encroachment on correctional operations, the PLRA places restrictions on the scope of prospective relief, defined as relief other than compensatory damages ${ }^{38}$ that courts can award in conditions-of-confinement cases. ${ }^{39}$ The PLRA also circumscribes when courts can issue "prisoner release orders," orders that have the purpose or effect of limiting the number of prisoners confined in a particular correctional facility. ${ }^{40}$

The PLRA further provides for the termination of prospective relief awards in conditions-of-confinement cases. ${ }^{41}$ Unless the prospective relief is needed to remedy a "current and ongoing" violation of a federal right, extends no further than necessary to correct that violation, is "narrowly drawn," and is the "least intrusive means" of rectifying the violation, the court must terminate the relief upon motion of a defendant or intervener. ${ }^{42}$ In addition, any preliminary injunction issued in a conditions-ofconfinement case expires ninety days after its issuance unless the court makes similar findings regarding the need for, and narrowness of, the injunctive relief. ${ }^{43}$

35. 42 U.S.C. § 1997e(e) (Supp. IV 1999).

36. 28 U.S.C. $\S 1915(\mathrm{~g})$.

37. Id.

38. 18 U.S.C. $\$ 3626(\mathrm{~g})(7)$ (Supp. 2000). Injunctions are a prototypical mechanism through which courts provide prospective relief. See, e.g., Miller v. French, 530 U.S. 327, 333 (2000) (analyzing the meaning and constitutionality of a PLRA provision staying prospective relief a certain period of time after the filing of a motion to terminate that relief).

39. Courts can award prospective relief only when such relief is "necessary" to correct a violation of a federal right. 18 U.S.C. $\$ 3626(\mathrm{a})(1)(\mathrm{A})$. In addition, the prospective relief must meet three somewhat duplicative requirements: the relief must be "narrowly drawn," must "extend no further than necessary" to remedy the violation, and must be "the least intrusive means" of rectifying the federal right violation. Id.

40. Id. $\S 3626(\mathrm{~g})(4)$. Courts can issue such an order only when a less intrusive order with which a defendant was given a reasonable amount of time to comply has not succeeded in remedying the violation. Id. $\$ 3626(\mathrm{a})(3)$ (A). In addition, a court cannot issue a prisoner-release order unless the court has found, by clear and convincing evidence, that crowding is the "primary cause" of the illegal conditions of confinement and that no other relief can redress that violation. Id. $\S 3626(\mathrm{a})(3)(\mathrm{E})$. Finally, only a three-judge court, comprised of at least one appellate judge and one or more district judges, can issue a prisoner-release order. $I d . \S 3626(\mathrm{a})(3)(\mathrm{B})$.

41. Id. $\S 3626(\mathrm{~b})$.

42. Id. § $3626(\mathrm{~b})(2)-(3)$.

43. Id. $\S 3626(\mathrm{a})(2)$. 
Finally, the PLRA places a number of constraints on the use of special masters, court-appointed experts assigned to oversee and facilitate the implementation of courts' remedial orders in conditions-of-confinement cases. ${ }^{44}$ The PLRA, for example, prohibits special masters from commumicating ex parte with the parties. ${ }^{45}$

\section{B. Restrictions an Attorney's Fees}

The Prison Litigation Reform Act restricts the recovery of attorney's fees by prisoners in four different ways. ${ }^{46}$ First, the PLRA limits the kinds of work for which attorney's fees can be awarded. Attorney's fees can be awarded when the fees were "directly and reasonably incurred" in proving an "actual violation" of the prisoner's rights provided that they also either meet a proportionality requirement ${ }^{47}$ or were "directly and reasonably incurred" in enforcing the court-ordered relief. ${ }^{48}$

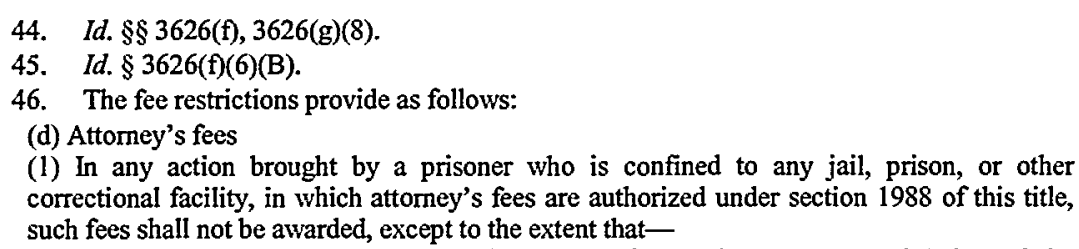

(A) the fee was directly and reasonably incurred in proving an actual violation of the plaintiff's rights protected by a statute pursuant to which a fee may be awarded under section 1988 of this title; and

(B) (i) the amount of the fee is proportionately related to the court ordered relief for the violation; or

(ii) the fee was directly and reasonably incurred in enforcing the relief ordered for the violation.

(2) Whenever a monetary judgment is awarded in an action described in paragraph (1), a portion of the judgment (not to exceed 25 percent) shall be applied to satisfy the amount of attorney's fees awarded against the defendant. If the award of attorney's fees is not greater than 150 percent of the judgment, the excess shall be paid by the defendant.

(3) No award of attorney's fees in an action described in paragmph (1) shall be based on an hourly rate greater than 150 percent of the hourly rate established under section $3006 \mathrm{~A}$ of Title 18, for payment of court-appointed counsel.

(4) Nothing in this subsection shall prohibit a prisoner from entering into an agreement to pay an attorney's fee in an amount greater than the amount authorized under this subsection, if the fee is paid by the individual rather than by the defendant pursuant to section 1988 of this title.

42 U.S.C. $\$ 1997$ (d) (Supp. IV 1999) (footnote omitted).

47. See infra text accompanying note 51 .

48. 42 U.S.C. $\$ 1997$ e(d)(1). It appears as though a clerical error occurred in the drafting of this section. As mentioned above, 42 U.S.C. $\$ 1997 \mathrm{e}(\mathrm{d})(1)$, as currently drafted, authorizes the recovery of fees incurred in proving a civil rights violation provided that one of two requirements is met: the fee is proportional to the relief the prisoner recovered or the fees were incurred when enforcing the courtordered relief. However, fees incurred in proving a civil rights violation are typically incurred before and during a trial or settlement, while those incurred during the enforcement stage of the litigation are incurred following the court's entry of its remedial order. In other words, fees falling within the rubric of 42 U.S.C. $\$ 1997$ (d)(1)(B)(ii) cannot also, as the PLRA appears to require, meet the requirement of 42 U.S.C. $\$ 1997 \mathrm{e}(\mathrm{d})(1)(A)$. See supra note 46 for the text of 42 U.S.C. $\$ 1997 \mathrm{e}(\mathrm{d})(1)$.

It therefore appears as though 42 U.S.C. $\$ 1997 \mathrm{e}(\mathrm{d})(1)(\mathrm{A})$ should be renumbered 42 U.S.C. $\$ 1997 \mathrm{e}(\mathrm{d})(1)(\mathrm{A})(\mathrm{i}), \quad 42 \quad$ U.S.C. $\$ 1997 \mathrm{e}(\mathrm{d})(1)(\mathrm{B})(\mathrm{i})$ should be renumbered 42 U.S.C. $\$ 1997 \mathrm{e}(\mathrm{d})(1)(\mathrm{A})(\mathrm{ii})$, and 42 U.S.C. $\$ 1997 \mathrm{e}(\mathrm{d})(1)(\mathrm{B})(\mathrm{ii)}$ should be renumbered 42 U.S.C. $\$ 1997 \mathrm{e}(\mathrm{d})(1)(B)$. The provision, as renumbered, would then read as follows: 
Second, in cases in which a prisoner was awarded monetary relief, the court must direct that a portion of the fee award be paid from the judgment. ${ }^{49}$ The PLRA, though, caps the amount of money that can be extracted from the judgment to pay the fee award at twenty-five percent. ${ }^{50}$ Thus, if a prisoner were awarded $\$ 1000$ in damages, the court would apply a portion of the award, not to exceed $\$ 250$, towards payment of the prisoner's attorney's fees.

Third, the PLRA contains both a general and a specific proportionality requirement. The general requirement simply directs that the fee award be "proportionately related" to the relief ordered by the court. ${ }^{51}$ The more specific requirement applies to cases in which the court awards monetary relief. In those cases, the sum due from the defendant to pay the fee award is capped at $150 \%$ of the judgment minus the amount debited from the judgment to pay the part of the fee award for which the prisoner-plaintiff is responsible. ${ }^{52}$ Thus, in a case in which the plaintiff is awarded $\$ 100$ in damages and in which the court directs that only a nominal sum of one dollar be applied from the judgment to pay the fee award, the court can require the defendant to pay, at most, $\$ 149$ in attorney's fees, $\$ 150(150 \%$ of the judgment) minus one dollar.

The fourth and final fee restriction in the PLRA limits the hourly rate that courts can utilize when calculating the fee award. The PLRA caps the rate at $150 \%$ of the rate established by the Criminal Justice Act (CJA) ${ }^{53}$ the statute under which attorneys representing indigent defendants charged with federal crimes are compensated. ${ }^{54}$

For some courts, ascertaining what the CJA rate is has proven to be a labyrinthine task. The CJA authorizes a maximum rate of $\$ 60$ per hour for in-court work and $\$ 40$ an hour for out-of-court work unless the Judicial Conference has authorized a higher rate, not to exceed $\$ 75$ an hour. ${ }^{55}$ The

(d) Attorney's fees

(1) In any action brought by a prisoner who is confined to any jail, prison, or other correctional facility, in which attorney's fees are authorized under section 1988 of this title, such fees shall not be awarded, except to the extent that-

(A) (i) the fee was directly and reasonably incurred in proving an actual violation of the plaintiff's rights protected by a statute pursuant to which a fee may be awarded under section 1988 of this title; and

(ii) the amount of the fee is proportionately related to the court ordered relief for the violation; or

(B) the fee was directly and reasonably incurred in enforcing the relief ordered for the violation.

No court, however, has yet recognized this apparent drafting error.

49. 42 U.S.C. $\$ 1997 \mathrm{c}(\mathrm{d})(2)$.

50. Id.

51. Id. $\$ 1997 \mathrm{e}(\mathrm{d})(1)(\mathrm{B})(\mathrm{i})$.

52. Id. $\S 1997 \mathrm{e}(\mathrm{d})(2)$.

53. Id. $\S 1997 \mathrm{e}(\mathrm{d})(3)$.

54. 18 U.S.C. $\$ 3006$ A(a) (1994).

55. Id. $\S 3006 \mathrm{~A}(\mathrm{~d})(1)$. 
Judicial Conference has approved a higher rate of $\$ 75$ an hour for both incourt and out-of-court work, ${ }^{56}$ but because of funding limitations, this $\$ 75$ rate has not been fully implemented in most federal court districts. ${ }^{57}$ While Congress has appropriated the funds to pay $\$ 75$ for attorneys' in-court time, it has appropriated only $\$ 55$ for their out-of-court time in most districts. ${ }^{58}$

The maximum hourly rate at which prisoners' attorneys can currently be compensated under the PLRA is therefore $\$ 112.50$ (150\% of $\$ 75$, the rate authorized by the Judicial Conference). ${ }^{59}$ But in some districts in which the $\$ 75$ rate has not been fully implemented because of budgetary constraints, courts have been using the appropriated figure ( $\$ 75$ and $\$ 55$ ) when computing the fee award in prisoners' cases. ${ }^{60}$ In these districts, the maximum hourly rate at which prisoners' attorneys can be compensated under 42 U.S.C. $\S 1988$ is $\$ 112.50$ for $\mathrm{m}$-court work and $\$ 82.50$ for out-ofcourt work (150\% of $\$ 55)$.

The restrictions the PLRA places on the recovery of attorney's fees apply only to "prisoners." The persons subject to these restrictions are, however, not just adults serving prison or jail sentences for crimes of which they were convicted. Individuals who have been charged with, but not convicted of, a crime are also subject to the fee restrictions, as are confined juveniles who have been adjudicated, or accused of being, delinquent. ${ }^{62}$

The PLRA's fee restrictions also do not apply to all lawsuits, or even all civil rights lawsuits, brought by persons denominated "prisoners" by the PLRA. The restrictions apply only in cases in which attorney's fees were awarded under one fee-award statute: 42 U.S.C. $\S 1988 .{ }^{63}$ Part II discusses the application and scope of this fee-award statute.

56. Defender Services Div., Admin. Off. of the U.S. Cts., Implementation of Criminal Justice Act Alternative Hourty Attorney Rates (Mar. 2001).

57. Id.

58. Id.

59. Madrid v. Gomez, 190 F.3d 990, 994 n.2 (9th Cir. 1999).

60. Compare Hernandez v. Kalinowski, 146 F.3d 196, 201 (3d Cir. 1998) (holding that the applicable rate for calculating attorney's fees is less than the Judicial Conference's $\$ 75$ hourly rate because the federal budget does not include the funds needed to implement that rate in the district), with llick v. Miller, 68 F. Supp. 2d 1169,1174 (D. Nev. 1999) (holding that the appropriated figure is irrelevant; the PLRA's hourly-rate restriction refers to the $\$ 75$ hourly rate "established" under the CJA, not to the hourly rate "paid" under the Act).

61. 42 U.S.C. $\$ 1997 \mathrm{e}(\mathrm{d})(1)$ (Supp. IV 1999).

62. The PLRA defines a "prisoner" subject to the fee restrictions as "any person incarcerated or detained in any facility who is accused of, convicted of, sentenced for, or adjudicated delinquent for, violations of criminal law or the terms and conditions of parole, probation, pretrial release, or diversionary program." Id. $\$ 1997 \mathrm{e}(\mathrm{h})$.

63. Id. $\$ 1997 \mathrm{e}(\mathrm{d})(1)$. Prisoners can also, for example, recover attorney's fees under the Americans with Disabilities Act. Id. $\$ 12205$. Federal prisoners who prevail in any civil action against the United States can obtain fee awards under 28 U.S.C. $\$ 2412$ (d)(1)(A). 28 U.S.C. $\$ 2412$ (d)(1)(A) (Supp. 2000). 
II

\section{FEe AWARDS UNDER 42 U.S.C. $\$ 1988$}

The way in which the fee-award statute, 42 U.S.C. $\S 1988(\mathrm{~b})$, applies to prisoners stands in stark contrast to the way in which the statute applies to nonprisoners. Set forth below is an overview of the standards that generally govern the award of attorney's fees under $\S 1988$. This overview is followed by a discussion of how those standards differ from the standards that, due to the PLRA, now apply to prisoners.

\section{A. \$ 1988: A General Overview}

Section 1988 authorizes a court to award "reasonable" attorney's fees to the "prevailing party" in lawsuits brought under a number of different civil rights statutes. ${ }^{64}$ One of the statutes triggering a fee award under $\S 1988$ is 42 U.S.C. $\S 1983$, a law designed to remedy violations of constitutional and other federal rights by persons acting "under color of" state law. The other civil rights statutes to which $\S 1988$ applies protect religious freedom; $;{ }^{65}$ prohibit employment discrimination, ${ }^{66}$ gender discrimination in educational programs that receive federal financial assistance, ${ }^{67}$ and racial or ethnic discrimination in the operation of "any program or activity" receiving federal financial assistance; ${ }^{68}$ and provide for the vindication of other civil rights. ${ }^{69}$

64. 42 U.S.C. $\S 1988(b)(1994)$. See infra text accompanying notes 65-69.

65. The Religious Freedom Restoration Act of 1993 (RFRA), 42 U.S.C. $\S 2000 \mathrm{bb}-1$ to -4 (1994), prohibits governmental officials from taking actions that "substantially burden" a person's exercise of his or her religion unless they further a "compelling" governmental interest and are the "least restrictive means" of furthering that interest. Id. $\S 2000 \mathrm{bb}-1$ (a), (b). Congress enacted the "Religious Land Use and Institutionalized Persons Act of 2000," Pub. L. No. 106-274, 114 Stat. 803 (codified at 42 U.S.C. $\S 2000 \mathrm{c}$ (c) (1999)), in an attempt to address the Supreme Court's concerns about RFRA's constitutionality. See City of Boeme v. Flores, 521 U.S. 507, 529-36 (1997) (holding that the RFRA could not constitutionally be applied to state and local officials because Congress had exceeded its power under section 5 of the Fourteenth Amendment in enacting the statute). The Religious Land Use and Institutionalized Persons Act prohibits govermments from placing a "substantial burden" on a confined person's exercise of his or her religious freedom unless the action resulting in that burden is the "least restrictive means" of furthering a "compelling" governmental interest. Id. $\$ 2000 \mathrm{cc}-1$ (a). Any person whose rights are violated under this Act can seek redress in court, including attomey's fees under $\S 1988$ (subject to the PLRA's restrictions). 42 U.S.C. $\$ 2000 c c-2(a)$, (d). But the Act applies only when a program or activity that receives federal subsidies imposes the protested burden or when the burden or its removal would have an impact on interstate commerce, international commerce, or commerce with Native-American tribes. Id. $\$ 2000 \mathrm{cc}-\mathrm{I}(\mathrm{b})$.

66. 42 U.S.C. $\$ 1981$ a (1994).

67. 20 U.S.C. $\$ 1681$ (1994).

68. 42 U.S.C. $\$ 2000 \mathrm{~d}(1994)$.

69. See 42 U.S.C. $\S 1981$ (1994) (prohibiting discrimination based on race or color); id. $\$ 1982$ (guaranteeing equal property rights to persons of all races and colors); id. $\$ 1985$ (authorizing lawsuits for damages against defendants who conspired to deprive plaintiffs of the equal protection of the law or other prescribed rights); $i d$. $\$ 1986$ (authorizing the bringing of such suits against certain individuals who could have, but failed to, prevent the wrongs inflicted by such a conspiracy); id. $\$ 13981$ (providing protection against gender-motivated, violent crimes). 
On its face, $\S 1988$ (b) does not require a court to award attorney's fees to the prevailing party. The decision whether or not to award fees is left to the court's discretion. ${ }^{70}$ The Supreme Court has, however, held that absent some "special circumstances" that would make a fee award under $\S 1988$ "unjust," courts should normally award attorney's fees to a prevailing plaintiff. ${ }^{71}$

In contrast, prevailing defendants are generally not entitled to a fee award under $\S 1988 .^{72} \mathrm{~A}$ court can direct the plaintiff to pay the prevailing defendant's attorney's fees only if the plaintiff's case was "frivolous, unreasonable, or without foundation, even though not brought in subjective bad faith." 73 The application of differing standards to prevailing plaintiffs and defendants stems from the concern that awarding attorney's fees as a general rule to prevailing defendants would undermine the core purpose of $\S 1988$ : to enforce the Constitution and certain civil rights laws by encouraging individuals whose rights have been violated to seek remedial relief from the courts. ${ }^{74}$

In determining what is a "reasonable" fee award, a court first calculates the "lodestar figure."75 The court computes this figure by multiplying the number of hours "reasonably expended" by the prevailing party's attorney on the case times a "reasonable" hourly rate. ${ }^{76}$ If the parties do not agree on these numbers, the party who has applied for a fee award has the burden of proving the reasonableness of both the number of hours spent working on the case and the hourly rate. ${ }^{77}$

Once a court has calculated the lodestar figure, it can consider additional factors that may result in an adjustment in the fee award. ${ }^{78}$ For example, a court can adjust a fee award upwards to compensate a plaintiff, and im turn the plaintiff's attorneys, for the delay in receiving payinent for work that was completed long ago. ${ }^{79}$ In addition, the court can take the plaintiff"s "level of success" mto account when determining what the final

70. See supra note 10.

71. Hensley v. Eckerhart, 461 U.S. 424, 429 (1983) (quoting S. REP. No. 94-1011, at 4 (1976) (quoting Newman v. Piggie Park Enters., Inc., 390 U.S. 400, 402 (1968))).

72. Hughes v. Rowe, 449 U.S. 5, 14-15 (1980) (per curiam).

73. Id. at 14 (quoting Christiansburg Garment Co. v. EEOC, 434 U.S. 412, 421 (1978)). In Hughes, the Supreme Court observed that courts should be especially reticent to award attorney's fees against pro se prisoners, since such fee awards would often be tantamount to punishing prisoners for their ignorance of legal requirements. Id. at 15.

74. Id. at 14-15.

75. City of Riverside v. Rivera, 477 U.S. 561,568 (1986).

76. Hensley, 461 U.S. at 433.

77. Id. at 437.

78. Id. at $434-36$.

79. Missouri v. Jenkins, 491 U.S. 274, $283-84$ (1989). Applying the market rate for the attomey's services prevailing at the time of the fee award instead of the rate that applied at the time the services were rendered is one way of compensating for this delay in payment. Id. at 284 . 
fee award should be.$^{80}$ If, for example, the plaintiff failed to prevail on a number of claims that were unrelated to the claim on which the plaintiff prevailed, the court should generally reduce the fee award to below the lodestar figure if that figure refiects time expended on those multiple nonmeritorious claims. ${ }^{81}$

\section{B. Differences Between the Attorney's Fees That Prisoners and Nonprisoners Can Recover Under § 1988}

The PLRA places restrictions on prisoners' recovery of attorney's fees under $\S 1988$ that do not apply to nonprisoners. Perhaps the most significant distinction is that nonprisoners are not subject to a requirement that the fee award be proportionately related to the relief ordered by the court. ${ }^{82}$ While a prevailing nonprisoner's level of success in a case may appropriately be factored into the computation of the final fee award ${ }^{83}$ the Supreme Court has specifically refused to read a proportionality requirement into $\S 1988$ like the one mandated for prisoners in $\S 1997 \mathrm{e}(\mathrm{d}){ }^{84}$

In City of Riverside v. Rivera ${ }^{85}$ eight nonprisoner-plaintiffs prevailed in their $\S 1983$ suit against a municipality and a number of police officers. The fee award of $\$ 245,456.25$ far exceeded the $\$ 33,350$ in damages awarded the plaintiffs. ${ }^{86}$ Nonetheless, the Supreme Court refused to find that the district court had abused its discretion in awarding attorney's fees in an amount over seven times higher than the amount of monetary relief. ${ }^{87}$ While acknowledging that the amount of damages is a relevant factor to be considered when computing a fee award, the Supreme Court spurned the suggestion that it should interpret $\S \mathrm{I} 988$ as including a proportionality requirement. ${ }^{88}$ The Court explained that such a requirement would be inconsistent with a central tenet underlying $\S 1988$ : a successful civil rights lawsuit benefits not just the plaintiff, but also the public, since the public has a stake in ensuring that constitutional and other civil rights are enforced. ${ }^{89}$ In addition, the enforcement of those rights deters people who might otherwise be inclined to disregard constitutional and other civil rights from doing so..$^{90}$

\footnotetext{
80. Hensley, 461 U.S. at 434.

81. Id. at 434-35.

82. City of Riverside v. Rivera, 477 U.S. 561,574 (1986).

83. See supra text accompanying notes $80-81$.

84. See supra text accompanying notes $51-52$ (describing general and specific proportionality requirements of $\S \S 1997 \mathrm{e}(\mathrm{d})(1)(\mathrm{B})(\mathrm{i})$ and $1997 \mathrm{e}(\mathrm{d})(2))$.

85. 477 U.S. 561 (1986).

86. Id. at 564-65.

87. Id. at 572-73.

88. Id. at 574 .

89. Id.

90. Id.
} 
The Supreme Court also observed in City of Riverside that a proportionality requirement would not comport with the reality that attorneys must often spend a substantial amount of time on constitutional rights cases even though the pecuniary awards in such cases are often low..$^{91}$ The Court recognized that if fee awards under $\S 1988$ had to be proportionate to the monetary relief recovered, the practical effect would be that attorneys would go uncompensated for their time "reasonably expended" litigating civil rights claims. ${ }^{92}$ For economic reasons, most attorneys could not afford to represent individuals whose civil rights had been violated. ${ }^{93}$ The end result of a proportionality requirement, then, would be that the objective of $\S 1988$, to attract competent counsel to represent imdividuals whose civil rights have been violated, would not be met. ${ }^{94}$

The second significant distimction between prisoners' and nonprisoners' recovery of attorney's fees under $\S 1988$ is that the hourly rate used when calculating the fee award for nonprisoners is not capped at $\$ 112.50 .^{95}$ Instead, courts apply the prevailing market rate for attorneys with similar skills, expertise, and experience when computing nonprisoners' fee awards. ${ }^{96}$ As a result, cases requiring the same amount of time for attorneys of comparable experience and ability to litigate may result in vastly higher fee awards for nonprisoners than for prisoners. In fact, nonprisoners may receive more substantial fee awards even when their cases consume much less attorney time than the prisoners' cases. ${ }^{97}$

A third way in which prisoner and nonprisoner plaintiffs are treated differently is that nonprisoners are not required by statute to pay any portion of the fee award in cases in which they obtam monetary relief. By contrast, courts in prisoners' cases inust direct that a part (though not to exceed twenty-five percent) of any judgment for monetary relief be applied to pay the fee award. ${ }^{98}$ Consequently, prisoners receive just a portion of the

\section{Id. at 577 .}

92. Id. at 578-79.

93. See id. at $579 \mathrm{n} .10$ (rejecting the argument that many attorneys would be willing to work on a case that would consume 2000 hours of their time over a ten-year period and for which they would be paid $\$ 5.65$ an hour).

94. Id. at 579.

95. See supra text accompanying notes 53-60 (explaining the current maximum rate to be used in calculating fee awards under the PLRA's hourly-rate restriction).

96. Blum v. Stenson, 465 U.S. 886, 895-96 \& n. 11 (1984).

97. Assume, for example, that the market rate for a particular attomey is $\$ 200$ an hour. In a nonprisoner's case on which the attomey worked 100 hours, the fee award under $\$ 1988$ would be $\$ 20,000$. By contrast, if the same attorney worked 150 hours on a case in which a prisoner prevailed, the fee award could not exceed $\$ 16,875$. If the prisoner's lawsuit was for monetary relief, the $150 \%$ fee cap might further diminish the fee award substantially, depending on the amount of damages awarded. See Walker v. Bain, 65 F. Supp. 2d 591, 595 (E.D. Mich. 1999) (reporting that the prevailing prisoner sought $\$ 36,046.25$ in attorney's fees, while the defendants claimed that the fees must be capped at $\$ 629,150 \%$ of the monetary judgment).

98. See supra text accompanying notes $49-50$. 
damages awarded for the injuries they sustained while nonprisoners can collect the full damages award.

Finally, the restrictions the PLRA places on the kinds of work coinpensable under $\S 1988$, work that was "directly and reasonably" related to "proving an actual violation" of the prisoner's rights and work that was "directly and reasonably related" to the enforcement of court-ordered relief, ${ }^{99}$ may also lead to differential treatment of prisoners under $\S 1988$. The extent to which prisoners will not recover fees for work that would be compensated in nonprisoners' cases is not yet clear, however, since courts are still fleshing out the meaning of these restrictions. For exaniple, the prevailing rule in most courts has been that when a nonprisoner's lawsuit precipitates changes that moot the lawsuit, the plaintiff can recover attorney's fees under $\S 1988 .{ }^{100}$ Courts are, however, divided on whether they can award attorney's fees when a prisoner's lawsuit was the catalyst for administrative reforms. ${ }^{101}$

Similarly, there is at least some doubt regarding the recoverability of attorney's fees for work expended preparing and litigating a petition for attorney's fees in a case brought by a prevailing prisoner-plaintiff. Traditionally, fees incurred for this kind of work have been recoverable under $\S 1988 .{ }^{102}$ And the Third Circuit Court of Appeals has held that courts can and should continue to award attorney's fees incurred preparing and litigating fee petitions in prisoners' cases. ${ }^{103}$ However, it is possible, perhaps

99. See supra text accompanying notes $47-48$.

100. See Friends of the Earth, Inc. v. Laidlaw Envtl. Servs., 528 U.S. 167, 194-95 (2000) (listing cases); see also 1 Mary Francis Derfner \& Arthur D. Wolf, Court Awarded Attorney Fees If 9.02, at 9-22 (2000). But see Buckhannon Bd. and Care Home, Inc. v. West Virginia Dep't of Health and Human Res., 121 S. Ct. 1835, 1843 (2001) (concluding as this article was going to press, in dicta, that the catalyst theory does not apply to fee awards under section 1988).

101. Compare, e.g., Waterman v. Farmer, 84 F. Supp. 2d 579, 586-87 (D.N.J. 2000) (holding that the PLRA abrogated the catalyst theory for fee recovery in prisoners' cases), with llick v. Miller, $68 \mathrm{~F}$. Supp. 2d 1169, 1172-73 (D. Nev. 1999) (holding that even though prisoners agreed to dismiss their lawsuit, they were prevailing parties entitled to a fee award because their lawsuit prompted changes in the prison's use-of-force policy and its provision of mental-health services).

The PLRA's legislative history contains a modicum of evidence that Congress intended to jettison the catalyst theory for fee recovery in conditions-of-confinement cases. See, e.g., H.R. REP. No. 10421 , at 28 (1995) (noting that limiting the recovery of attomey's fees in conditions-of-confinement cases to prisoners who prove an "actual violation" of thcir federal rights "will eliminate . . . attorney fees that penalize voluntary improvements in prison conditions").

102. See Hernandez v. Kalinowski, 146 F.3d 196, 198-99, 199 n.1 (3d Cir. 1998) (listing cases holding that $\S 1988$ authorizes the recovery of fees incurred preparing and litigating a fee petition).

103. See id. at 199-201. The Third Circuit expressed concern that if prevailing prisoners could not recover "fees on fees," their attorneys would not be fully reimbursed, as the PLRA envisioned, for their time expended proving an "actual violation" of their clients' rights, because the uncompensated time spent preparing and litigating the fee petition would diminish the amount of the total fees recovered. Id. at 199. The court also predicted that interpreting the PLRA as barring "fees on fees" would encourage defendants to resist paying prevailing prisoners' attorney's fees, prompting litigation regarding the fees owed. $I d$. at 200 . Such a result, the court concluded, would be at odds with the PLRA's purposes: to curb frivolous litigation and conserve judicial resources for meritorious claims. Id. 
even likely, that other courts will disagree that such fees were "directly and reasonably incurred in proving an actual violation" of a prisoner's rights. ${ }^{104}$

\section{III}

An Equal Protection Analysis of the Differential Application of $\S 1988$ TO PRISONERS

This Part analyzes the constitutionality of the two PLRA fee restrictions that are most likely to curtail prisoners' ability to bring and effectively litigate civil right suits: the $150 \%$ fee cap and the hourly-rate restriction. ${ }^{105}$ The central constitutional question concerning the PLRA's restrictions on attorney's fees is whether the differential treatment of prisoners and nonprisoners under $\S 1988$ violates prisoners' right to the equal protection of the law. This right finds its source in two constitutional provisions. The Fourteenth Amendment, which applies to state and local governments, explicitly guarantees individuals the right to be afforded "equal protection of the law." The Fifth Amendment, which applies to the federal government, does not specifically refer to the right to equal protection, but courts have held that this right is subsumed within the right to due process of law set forth in that amendment. ${ }^{106}$ Since the Prison Litigation Reform Act is a federal statute, the fee restrictions in the PLRA implicate the equal protection safeguard found in the Fifth Amendment. ${ }^{107}$

\section{A. Are Prisoners and Nonprisoners "Similarly Situated"?}

When undertaking an equal protection analysis, the threshold inquiry is whether the two groups of individuals treated differently by a statute are "similarly situated." "108 If they are not, then the statute's discrepant treatment of the two groups does not implicate the requirements of equal protection. For example, if a statute levies an income tax on adults, but not sinall children, a court need not belabor itself determining whether the statute satisfies the applicable two-pronged equal protection standard. ${ }^{109}$

104. The House Report on H.R. 667 noted that the actual-violation requirement for fee recovery "eliminates the financial incentive for attorneys to litigate ancillary matters, such as attorney fee petitions ...." H.R. REP. No. 104-21, at 28.

105. The PLRA's other fee restrictions are potentially less likely to impair prisoners' civil rights suits. Courts can limit the impact of the prisoner-contribution requirement by requiring prisoners to pay a nominal sum towards the fee award. See, e.g., Morrison v. Davis, 88 F. Supp. 2d 799, 801, 811 (S.D. Ohio 2000) (assessing one dollar from a $\$ 15,000$ judgment to pay the prisoner's attomey's fees). In addition, an analysis of the constitutionality of the restrictions on the type of work that can trigger a fee award in prisoners' cases is premature until the courts have fleshed out the mcaning and import of these restrictions.

106. See, e.g., Bolling v. Sharpe, 347 U.S. 497, 500 (1954).

107. Hadix v. Johnson, 230 F.3d 840, 842 (6th Cir. 2000).

108. City of Cleburne v. Cleburne Living Ctr., 473 U.S. 432,439 (1985).

109. See infra text accompanying notes 118-122 for a discussion of the different equal protection tests. 
The statute clearly passes constitutional muster from an equal protection standpoint because small children and adults are not similarly situated for revenue-generation purposes; sinall children are not einployed and receive no income upon which a tax could be levied.

Consequently, the question that must first be addressed when assessing the constitutionality of the PLRA's fee restrictions is whether prevailing prisoners and nonprisoners seeking attorney's fees under $\S 1988$ are similarly situated. Because prisoners have reduced liberty and are subject to innumerable restrictions inapplicable to nonprisoners, the visceral response to this question might be that they are not.

In Boivin v. Black, ${ }^{110}$ the First Circuit Court of Appeals intimated that it may subscribe to this view that prisoners and nonprisoners are not similarly situated for the purposes of equal protection law. The court stated that it need not examine the particular legislative purposes invoked in support of the constitutionality of the PLRA's fee cap because prisons are "sui generis."111 In other words, the court seemed to be saying that because of what it described as the "idiosyncratic characteristics" of the prison environment, ${ }^{112}$ prisoners are inherently dissimilar from nonprisoners. ${ }^{113}$

It is a truism that correctional institutions differ substantially from noncorrectional settings. This self-evident point, though, does not mean that all laws adversely affecting prisoners are exempt from scrutiny under equal protection, as is clear from Supreme Court case law. For example, in Rinaldi $v$. Yeager, ${ }^{114}$ the Court held that requiring certain indigent prisoners, but not nonprisoners, to reimburse counties for the costs of their transcripts on appeal violated the prisoners' right to the equal protection of the law. ${ }^{115}$ And in Baxstrom v. Herold,${ }^{116}$ the Supreme Court held that equal protection gave allegedly mentally ill prisoners facing a civil commitment at the end of their prison sentences the same right to a jury trial that the state afforded nonprisoners facing civil commitment. ${ }^{117}$

As Rinaldi and Baxstrom confirm, prisoners are not ipso facto dissimilarly situated, and therefore, statutes subjecting prisoners to unequal

110. 225 F.3d 36 (1st Cir. 2000).

111. Id. at 44. Boivin is not a model of clarity. Although the court insisted that it need not scrutinize the fee cap's alleged purposes, the court later conducted what it described as a "rational basis review," analyzing in depth the relationship between the distinctive treatment of prisoners under $\S 1988$ and one of the fee cap's touted purposes: the deterrence of frivolous prisoners' lawsuits. Id. at 45 .

112. Id. at 44 .

113. See also Allen v. Cuomo, 100 F.3d 253, 260 (2d Cir. 1996) (concluding that surcharges assessed against prisoners convicted of disciplinary infractions do not violate equal protection because prisoners and nonprisoners who pay other kinds of surcharges are not similarly situated).

114. 384 U.S. 305 (1966).

115. Id. at 308. See infra text accompanying notes 184-190 for further discussion of Rinaldi.

116. 383 U.S. 107 (1966).

117. Id. at 110. The Supreme Court also held in Baxstrom that, like nonprisoners, prisoners whose sentences were expiring could not be committed to a mental-health facility operated by the Department of Corrections without a judicial finding that they posed a danger to others. Id. 
treatment are not insulated from equal protection review. Additionally, Rinaldi seems to foreclose the argument that prevailing prisoners applying for attorney's fees under $\S 1988$ are not similarly situated with nonprisoners seeking fee awards under $\S 1988$. The Supreme Court in Rinaldi struck down a statute that resulted in heightened litigation costs for prisoners as compared to nonprisoners, the same type of disparate treatment resulting from the application of the PLRA's fee restrictions.

Concluding that prisoners and nonprisoners who bring meritorious civil rights suits are similarly situated does not necessarily mean that any difference in the amount of attorney's fees awarded prevailing prisoners, as compared to nonprisoners, under $\S 1988$ violates prisoners' right to the equal protection of the law. This conclusion does mean, however, that the rationale for distinguishing between prisoners and nonprisoners when awarding attorney's fees under $\S 1988$ must be examined before a decision can be made regarding the constitutionality of the PLRA's fee restrictions.

\section{B. The Appropriate Test: Strict Scrutiny or Rational Basis?}

The next question to resolve when determining whether a statute violates the right to equal protection of the law is: What test should be applied when determining whether a statute passes constitutional muster? Courts typically apply one of three equal protection tests, depending on the circumstances. Under the first test, known as the strict scrutiny test, a statute must be narrowly tailored to further a "compelling" governmental interest. ${ }^{118}$ Courts apply this test to statutes that place differing restrictions on persons based on a "suspect" criterion, such as race, as well as to those that burden the exercise of what are considered "fundamental rights." 19

The second equal protection test, which is applied to the majority of all other statutes, is much more lax, both in its iteration and application. This test, known as the rational basis test, requires only that a statute that treats similarly situated individuals differently be rationally related to a "legitimate" governmental interest. ${ }^{120}$

The third equal protection test provides for an intermediate level of review falling between the rigorous strict scrutiny test and the lenient rational basis test. To pass muster under this intermediate test, a classification must bear a "substantial relationship" to an "important" governmental interest ${ }^{121}$ Application of this test is confined to a discrete number of classifications, generally those based on gender and illegitimacy. ${ }^{12}$

118. Shaw v. Hunt, 517 U.S. 899,908 (1996).

119. Vacco v. Quill, 521 U.S. 793, 799 (1997).

120. Romer v. Evans, 517 U.S. 620, 631 (1996).

121. Clark v. Jeter, 486 U.S. 456, 461 (1988).

122. Id. 
Consequently, at this point in the evolution of equal protection law, this intermediate test can be put aside when determining which equal protection test applies to the PLRA's fee restrictions.

The strict scrutiny and the rational basis tests have two similar components. Both require, first, that a particular kind of governmental interest justify the differential treatment under the statute, and second, that there be a prescribed link between the statute and the governmental interest purportedly furthered by the statute.

The two tests differ, though, in terms of the substantiality of the governmental interest needed to validate the differential treatment, "compelling" versus "legitimate," and the nature of the relationship that must exist between the statute and that interest. Under the strict scrutiny test, the statute must be narrowly contoured to achieve the compelling governmental interest. The rational basis test, however, requires only a rational relationship between the end (the legitimate governmental objective) and the means to that end (the statute whose constitutionality is at issue).

If prisoners were considered a "suspect class," the PLRA's fee restrictions would have to meet the elevated requirements of the strict scrutiny test. A "suspect" criterion is one that is so infrequently related to the realization of a legitimate governmental objective that its invocation as a reason for differential treatment is usually the mark of enmity and prejudice. ${ }^{123}$ Race and national origin are classic examples of suspect criteria. ${ }^{124}$ The criterion of being imprisoned simply does not meet the threshold requirement to be considered "suspect;") many of the restrictions to which prisoners, but not nonprisoners, are subject serve obviously legitimate governmental interests, such as the need to protect institutional security. ${ }^{126}$ Courts have therefore uniformly held that prisoners are not a "suspect class," "127 and that the PLRA's fee restrictions need only meet the demands of rational basis.

The rational basis test is premised on the assumption that misguided laws will eventually be changed through the political process. ${ }^{128}$ Arguably,

123. City of Cleburne v. Clebume Living Ctr., 473 U.S. 432, 440 (1985).

124. Id.

125. Cf. Jones v. North Carolina Prisoners' Labor Union, Inc., 433 U.S. 119, 125 (1977) (noting that "'[1]awful incarceration brings about the necessary withdrawal or limitation of many privileges and rights, a retraction justified by the considerations underlying our penal system"') (quoting Price v. Johnston, 334 U.S. 266, 285 (1948)).

126. See, e.g., id. at 129 (finding that a prison rule prohibiting inmates from holding union meetings was rationally related to institutional security).

127. See, e.g., Hadix v. Johnson, 230 F.3d 840, 843 (6th Cir. 2000); Boivin v. Black, 225 F.3d 36, 42 (1st Cir. 2000); Zehner v. Trigg, 133 F.3d 459, 463 (7th Cir. 1997).

128. See infra text accompanying note 141; see also Plyler v. Doe, 457 U.S. 202, 218 n.14 (1982) (holding that the strict scrutiny test applies to the differential treatment of groups that "have historically been 'relegated to such a position of political powerlessness as to command extraordinary protection from the majoritarian political process"') (quoting San Antonio Indep. Sch. Dist. v. Rodriguez, 411 U.S. 1, 28 (1973)). 
this premise is unfounded as applied to prisoners, most of whom are disenfranchised $d^{129}$ and almost all of whom are maligned by politicians and the public alike. ${ }^{130}$ However, the courts have shown no inclination to apply a more rigorous equal protection test to laws having a differential impact on prisoners, ${ }^{131}$ avoiding the uproar that would likely ensue if prisoners were viewed as receiving broader constitutional protection than law-abiding citizens. To the courts, prisoners may be, as prison officials pejoratively observed in one case, "'a class of suspects, but they are not a suspect class." 132

The only remaining argument for applying the strict scrutiny test to the PLRA's fee restrictions is that they impinge on a fundamental right. The Supreme Court has indeed recognized that the right to have access to the courts is a fundamental right. ${ }^{133}$ However, the Court has also held that the failure to provide counsel to prisoners to assist them in litigating constitutional claims does not abridge inmates' right of access to the courts. ${ }^{134}$ It is therefore difficult to conceive that courts would conclude that restrictions on the fees awarded to pay for those attorneys violate that fundamental right. Rather, it appears that courts will apply the rational basis test in analyzing the constitutionality of the PLRA's fee restrictions.

\section{Application of the Rational Basis Test to the PLRA'S $150 \%$ Fee Cap and Hourly-Rate Restrictions}

\section{Governing Principles}

Several basic principles govern the assessment of a statute's constitutionality under the rational basis test. The common link between all of these principles is the theme that the judicial branch of the government should defer to the policy judgments of the legislative branch and interfere

129. In 1996, forty-six states barred prisoners from voting, all but Maine, Massachusetts, Utah, and Vermont. The Sentencing Project \& Human Rughts Watch, Losing the Vote: The Impact of Felony Disenfranchisement Laws in the United States 1, 3 (1998).

130. See Hudson v. Palmer, 468 U.S. 517, 557 (1984) (O'Connor, J., concurring) ("Disenfranchised, scomed and feared, often deservedly so, shut away from public view, prisoners are surely a 'discrete and insular minority."') (quoting Bernal v. Fainter, 467 U.S. 216, 222 n.7 (1984)).

131. See, e.g., Jones, 433 U.S. at 134 (applying a rational basis test to a prison regulation prohibiting prisoner union meetings but allowing prisoners to meet with other groups, such as the Jaycees). But cf. Brian B. v. Penn. Dep't of Educ., 230 F.3d 582, 590 (3d Cir. 2000) (Roth, J., dissenting). Judge Roth argues:

While we do not consider prisoners a suspect class, they represent a group to whom the legislature has limited politieal accountability. Yet political accountability is central to rational basis review .... Thus, while certainly not requiring a heightened level of scrutiny, even under rational basis review, limited political accountability obligates a court to 'insist on knowing the relation between the classification adopted and the object to be attained.'

Id. at 590 (citation omitted) (quoting Romer v. Evans, 517 U.S. 620, 632 (1996)).

132. Zehner v. Trigg, 952 F. Supp. 1318, 1333 n.12 (S.D. Ind. 1997) (quoting Defendant's brief at 18-19), affd, 133 F.3d 459 (7th Cir. 1997).

133. Bounds v. Smith, 430 U.S. 817, 828 (1977).

134. Lewis v. Casey, 518 U.S. 343, 354 (1996). 
with those judgments only when it is clear that they transgress constitutional boundaries.

The first governing principle is that courts are to presume that statutes challenged on equal protection grounds are constitutional. ${ }^{135}$ Only if the plaintiff rebuts this presumption will a court strike down a statute as violative of the right to equal protection of the law. And the burden placed on a plaintiff to rebut this presumption is an onerous one. It will not suffice if the plaintiff demonstrates that the interest cited by the legislature to justify the differential treatment of similarly situated individuals is not legitimate or that the statute is not sufficiently linked to a legitimate governmental interest. Instead, the plaintiff must show that the statute does not further any "conceivable" legitimate governmental interest that might arguably support this legislation, regardless of whether or not the legislature enacted the statute with this interest in mind. ${ }^{136}$

The second principle governing courts' equal protection analyses under the rational basis test is that laws that are ill-advised and even inane are not necessarily, and in fact not usually, unconstitutional. ${ }^{137}$ The Supreme Court has underscored this principle to the point that it has become a familiar refrain: "We do not inquire whether this statute is wise or desirable. . . Misguided laws may nonetheless be constitutional."138

A third related principle applied when determining whether a statute comports with the requirements of equal protection is that the limes the legislature draws between groups to effectuate a legitimate governmental objective need not be drafted with complete precision. As the Supreme Court has observed, legislative classifications need not be "perfectly calibrated"139 or crafted with "mathematical nicety"140 in order to meet equal protection requirements.

The final principle, perhaps better described as an assumption, underlying the courts' approach to equal protection is that relief from foolhardy laws can and will eventually come from the legislature. As the flaws in laws and the unfairness they engender become evident, the democratic

135. City of Cleburne v. Cleburne Living Ctr., 473 U.S. 432,440 (1985).

136. Heller v. Doe, 509 U.S. 312, 320-21 (1993) ("The burden is on the one attacking the legislative arrangement to negative every conceivable basis which might support it,' whether or not the basis has a foundation in the record.") (quoting Lehnhausen v. Lake Shore Auto Parts Co., 410 U.S. 356,364 (1973)).

137. See, e.g., FCC v. Beach Communications, Inc., 508 U.S. 307, 313 (1993) ("[E]qual protection is not a license for courts to judge the wisdom, faimess, or logic of legislative choices."); Vance v. Bradley, 440 U.S. 93, 97 (1979) ("[J]udicial intervention is generally unwarranted no matter how unwisely we may think a political branch has acted.").

138. James v. Strange, 407 U.S. 128, 133 (1972).

139. Bankers Life and Casualty Co. v. Crenshaw, 486 U.S. 71, 85 (1988).

140. Dandridge v. Williams, 397 U.S. 471, 485 (1970) (quoting Lindsley v. Natural Carbonic Gas Co., 220 U.S. $61,78(1911)$ ). 
process will, it is felt, at some point work to correct those flaws or set the laws aside. ${ }^{141}$

\section{Conceivable Governmental Interests Underlying the PLRA's Fee Restrictions}

A survey of the PLRA's legislative history might illuminate what conceivable government mterests might be invoked to defend the constitutionality of the PLRA's fee restrictions. As mentioned above, ${ }^{142}$ the PLRA had two chief purposes: to curb the filing of frivolous prisoners' lawsuits and to end what Congress, or at least some members of Congress, considered judicial micromanagement of correctional imstitutions. It is not clear from the PLRA's sparse legislative history whether Congress considered the fee restrictions as tools to effectuate one of these objectives, both of these objectives, or some other undefined purposes.

Much of the PLRA's legislative history emerges from H.R. 667, a crime-control bill passed by the House of Representatives in February of 1995 that contained the precursors to the PLRA: the "Stopping Abusive Prisoner Lawsuits Act"143 and the "Stop Turning Out Prisoners Act."144 The "Stop Turning Out Prisoners Act" included two limitations on the attorney's fees prisoners could recover under 42 U.S.C. $\$ 1988$ : a requirement that the fees were incurred "directly and reasonably" in the course of proving a violation of the prisoner's federal rights and a requirement that the fees be proportionate to the court-ordered relief. ${ }^{145}$ H.R. 667 did not contam either the $150 \%$ fee cap or the hourly-rate restriction.

The Report of the House Committee on the Judiciary briefly discussed the purposes of the two fee restrictions in H.R. 667. ${ }^{146}$ The Report noted that limiting attorney's fees to those incurred in proving an actual violation of a federal right would foreclose the recovery of fees for nonmeritorious claims, thereby abolishing what the Report described as the "financial incentive" to include such claims in prisoners' complaints. ${ }^{147}$ The Report asserted, however, that the actual-violation requirement preserved the

141. See Vance, 440 U.S. at 97 ("[E]ven improvident decisions will eventually be rectified by the democratic process. ..."). For a discussion of the untenability of this principle in the prisoner context, see supra notes 128-129 and accompanying text and note 131 .

142. See supra notes $29-30$ and accompanying text.

143. H.R. 667, 104th Cong. $\$ \$ 201-204$ (1995).

144. Id. $\$ 301$.

145. Id. $\S 301(a)$. The Stop Tuming Out Prisoners Act included these two fee restrictions, along with limitations on the prospective relief courts can award in conditions-of-confinement cases, as amendments to 18 U.S.C. $\$ 3626$. Id. The section of the bill that contained the restrictions on attorney's fees and prospective relief was entitled, "Appropriate Remedies for Prison Conditions." Id.

146. H.R. REP. No. 104-21, at 28 (1995).

147. Id. The House Report may have overstated the extent to which there exists such a financial incentive. In Hensley v. Eckerhart, 461 U.S. 424, 436-37 (1983), the Supreme Court held that the litigation of nonmeritorious claims may lead to a reduction in the fees awarded a prevailing plaintiff. See supra text accompanying notes 80-81. 
financial incentive to file lawsuits to remedy actual violations of prisoners' federal rights. ${ }^{148}$

The House Report's discussion of the purposes of the proportionality requirement, the requirement that the attorney's fees awarded prisoners be proportionally related to the relief ordered by the court, is particularly relevant because the $150 \%$ fee cap can be viewed as simply a more specific delineation of how the proportionality requirement should be applied in suits for monetary relief. ${ }^{149}$ The House Report concluded that the proportionality requirement would "discourage burdensome litigation of insubstantial claims where the prisoner can establish a technical violation of a federal right but he suffered no real harm from the violation." 150 According to the House Report, the proportionality requirement would also serve to "remind" judges that the attorney's fees they award should not "unreasonably exceed" the amount of damages a prisoner recovers. ${ }^{151}$

While the House records offer some, though limited, insight into the purposes of the fee restrictions in H.R. 667, the Senate records pertaining to fee restrictions are sketchy. While the Senate Judiciary Committee held hearings on H.R. $667,{ }^{152}$ the Committee did not report the bill out. Instead, on September 27, 1995, Senator Dole introduced a different, though related, bill in the Senate entitled, "The Prison Litigation Reform Act of 1995."153 Rather than being steered to the Senate Judiciary Committee for analysis and review, the Senate inserted the PLRA two days later into an omnibus appropriations bill that the Senate passed on the same day. ${ }^{154}$

148. H.R. ReP. No. 104-21, at 28.

149. See Boivin v. Black, 225 F.3d 36, 40 n.3 (1st Cir. 2000) ("In section 1997e (d)(2), Congress presumably decided to take advantage of the precision available when relief is limited to money damages and to define proportionality in more specific terms.").

150. H.R. REP. No. 104-21, at 28.

151. Id.

152. Ten witnesses testified at the Senate hearing about the precursor to the PLRA found in H.R. 667. See Prison Reform; Enhancing the Effectiveness of Incarceration: Hearing on S. 3, S. 38, S. 400, S. 866, S. 930, H.R. 667 Before the Senate Comm. on the Judiciary, 104th Cong. 9-16, 20-101, 107-08, 111-13, 141 (1995); see id. at 10-11, 13-16, 20-25 (testimony and statement of John Schmidt, Associate Attorney General, United States Department of Justice, Washington, D.C.), reprinted in 2 BERNARD D. Reams \& William H. Manz, Legislative History of the Prison Litigation Reform Act of 1996, at Doc. 55 (1997) [hereinafter 2 ReAms \& MANZ]; id. at 26-101 (panel consisting of William P. Barr, former Attorney General, United States Department of Justice, Washington, D.C.; Paul T. Cappuccio, Kirkland and Ellis, Washington D.C.; John J. Dilulio, Jr., Professor of Politics and Public Affairs, Princeton University; Lynne Abraham, District Attorney, Philadelphia, Pennsylvania, on behalf of the National District Attorneys Association; Michael Gadola, Director, Office of Regulatory Reform, Michigan; Robert J. Watson, Commissioner of Correction, Delaware; and Steve J. Martin, former General Counsel, Texas Department of Corrections); id. at 107-09, 111-13 (testimony and statement of panel member O. Lane McCotter, Executive Director, Utah Department of Corrections); id. at 141 (statement of panel member James A. Collins, Executive Director, Texas Department of Criminal Justice).

153. 141 Cong. Rec. S14,413-17 (1995) (statement of Sen. Dole and text of S. 1279).

154. Id. at S14,626 (statement of Sen. Hatch); id. at S14,756-59 (text of Amendment No. 2838 to H.R. 2076). 
Although President Clinton vetoed the conference version of this bill, ${ }^{155}$ the PLRA was reinserted into an appropriations bill several months later and enacted into law in April of 1996. ${ }^{156}$

The Senate sponsors of the PLRA added, without any explanation, new and significant restrictions on the attorney's fees recoverable by prisoners under $\S 1988$, including the prisoner-contribution requirement, ${ }^{157}$ the $150 \%$ cap, and the hourly-rate restriction. The PLRA's fee restrictions, unlike the restrictions in H.R. 667, were not included in the section of the Act curtailing the scope of remedial relief in conditions-of-confinement cases. ${ }^{158}$ Instead, the fee restrictions were ensconced in the section of the legislation whose touted purpose was to curb frivolous inmate litigation. ${ }^{159}$

Nowhere in the PLRA's legislative history is there any mention of the reasons why the $150 \%$ cap was added to the PLRA, although Senator Abraham, a sponsor of the PLRA, ${ }^{160}$ did briefly mention the purpose of the PLRA's general proportionality requirement: 'No longer will attorneys be allowed to charge massive amounts to the State for the service of correcting minimal violations." tionale underlying the hourly-rate restriction: " $[\mathrm{N}]$ o longer will attorneys be allowed to charge very high fees for their time."162 In part because normal channels were not followed in enacting the PLRA, ${ }^{163}$ it is therefore not

155. 141 CoNG. REc. H15,166-67 (1995).

156. Omnibus Consolidation Rescissions and Appropriations Act of 1996, Pub. L. No. 104-134, 110 Stat. 1321 (1996).

157. See supra text accompanying notes 49-50.

158. Section 802 of the PLRA, denominated "Appropriate Remedies for Prison Conditions," contained these restrictions on the remedial relief in conditions-of-confinement cases. Prison Litigation Reform Act, Pub. L. No. 104-134, § 802, 110 Stat. 1321-66 (1996).

159. Id. $\S 803$. Senator Dole observed that the provisions in this section of the PLRA would "go a long way to take the frivolity out of frivolous inmate litigation." 141 CoNG. REC. S14,414 (1995). When listing the provisions that would have this effect, however, Senator Dole did not mention the fee restrictions. Id. at S14,413-14.

160. See id. at $S 14,413, \mathrm{~S} 14,418$.

161. Id. at $\mathrm{S} 14,317$.

162. Id.

163. Several members of Congress strongly criticized the failure to vet the PLRA through the Senate and House Judiciary Committees. Representative Mollohan remonstrated:

The issues addressed by these three legislative proposals are in the jurisdiction of the Committee on the Judiciary. These items include a major legislative rewrite of the Truth in Sentencing initiative grants, prison litigation reform and Legal Services Corporation. All these provisions amend current law and have impacts that are not clearly defined, despite the claims of the Committee on the Judiciary. The reasons they have ended up in this appropriations bill are unclear to me, because as far as $1 \mathrm{know}$, we still have a Committee on the Judiciary with an especially competent chairman and ranking member, and 1 see no reason why an appropriations bill should contain such extensive authorizing language.

141 CoNG. REC. H14,098 (1995) (statement of Rep. Mollohan).

Senator Kennedy voiced similar objections:

Although a version of the PLRA was introduced as a free-standing bill and referred to the Judiciary Committee, it was never the subject of a committee mark-up, and there is no Judiciary Committee report explaining the proposal. The PLRA was the subject of a single 
at all clear what purposes Congress contemplated would be served by the $150 \%$ cap and the hourly-rate restriction on prisoners' attorney's fees. In fact, it is highly unlikely that Congress contemplated the provisions' purposes or even contemplated the provisions at all, since they were not the subject of a congressional report or, with the single exception of Senator Abraham's cryptic reference to the hourly-rate restriction, the focus of congressional discussion or debate.

Despite the dearth of specific feedback from Congress regarding the $150 \%$ cap and the hourly-rate restriction, it is possible to extrapolate four interests from the legislative history of the PLRA that might be posited to support the two fee restrictions: (1) the interest in curtailing frivolous inmate litigation; ${ }^{164}(2)$ the interest in discouraging inmates from filing "low-value" lawsuits;, ${ }^{165}$ (3) the interest in saving taxpayers' money; ${ }^{166}$ and (4) the interest in curbing federal-court intervention in correctional operations. ${ }^{167}$ Whether any of these interests can, from an equal protection standpoint, justify the differential treatment of prisoners and nonprisoners under $\S 1988$ is discussed below.

\section{a. Curbing Frivolous Lawsuits by Prisoners}

As mentioned above, ${ }^{168}$ one of the Prison Litigation Reform Act's principal purposes was to curb prisoners' filing of frivolous lawsuits. This purpose is undoubtedly legitimate because of the costs incurred processing and defending against such claims. ${ }^{169}$ But are the $150 \%$ fee cap and the hourly-rate restriction rationally related to this purpose?

hearing in the Judiciary Committee, hardly the type of thorough review that a measure of this scope deserves.

142 Cong. Rec. S2296 (1996) (statement of Sen. Kennedy); see also id. at S2297 (statement of Sen. Simon) ("l am very discouraged that this legislation was considered as one of the many issues on an appropriations bill. Legislation with such far reaching implications certainly deserves to be thoroughly examined by the committee of jurisdiction and not passed as a rider to an appropriations bill.").

164. See supra text accompanying note 159.

165. See supra text accompanying note 161; see also Boivin v. Black, 225 F.3d 36, 46 (Ist Cir. 2000).

166. See supra text accompanying note 161-162.

167. See supra text accompanying note 30 .

168. See supra text accompanying note 29.

169. The National Association of Attorneys General (NAAG), a proponent of the PLRA, estimated in a letter to Senator Dole in 1995 that the litigation of prisoners' civil rights suits costs states $\$ 81.3$ million dollars per year. 141 CONG. REC. S14,417-18 (1995). NAAG further reported that most of this money was expended on nonmeritorious, including frivolous, claims. Id. at $\$ 14,418$.

While conducting a study on pro se inmate litigation for the American Bar Association under a grant from the Bureau of Justice Assistance of the U.S. Department of Justice, see LYNN S. BRANHAM, Limiting the Burdens of Pro Se Inmate Litigation: A Technical-Assistance Manual for Courts, Correctional OfFicials, and AtTorneys General (1997), the author requested the data from which the $\$ 81.3$ million dollar figure had been extrapolated. NAAG refused, however, to reveal any information from which the validity of this figure could be assessed, explaining that the information collected from NAAG members was intended "only to provide members with an informed estimate." Letter from Layne M. Lindebak, Acting State lnitiatives Counsel, NAAG, to Lynn S. 
At first glance, the question seems nonsensical because courts award attorney's fees only in cases in which the prisoners prevailed, cases in which the prisoners' claims were not only nonfrivolous, but ineritorious. But several courts have cited this interest in upholding the constitutionality of the fee restrictions. ${ }^{170}$ For example, in concluding that the $150 \%$ fee cap did not abridge equal protection requirements, the First Circuit Court of Appeals proffered what it considered two "conceivable" ways in which the cap might reduce the filing of frivolous prisoner lawsuits. ${ }^{171}$ First, the fee cap might induce prisoners to refrain from filing frivolous claims since attorneys, faced with the prospect of a low fee award due to the cap, would be unwilling to represent them. ${ }^{172}$ Second, the fee cap would dissuade attorneys from encouraging prisoners to file frivolous lawsuits:

[T]o the extent that Congress thought lawyers were exhorting prisoners to pursue frivolous claims in the hope that lightning would strike-that, say, a runaway jury would hand down a favorable verdict or a sympathetic judge would couple a smidgen of relief with a large fee award - the fee cap would tend to curtail that behavior, thereby reducing the overall number of frivolous suits in the system. ${ }^{173}$

These expositions of the fee cap's hypothetical effects, as well as similar pronouncements by other courts about the hourly-rate restriction, ${ }^{174}$ however, are shibboleths, founded in neither fact nor logic. In reality, the fee restrictions are unrelated to attorneys' already existing and longstanding unwillingness to represent prisoners who want to bring frivolous claims. A frivolous claim is one that is not evcn argnably supported by the facts or the law. ${ }^{175}$ Lawyers refuse to represent prisoners with such claims because attorneys cannot be compensated under $\S 1988$ for any work

Branham (Oct. 4, 1996) (on file with author). NAAG further stated that when collecting information from its members, NAAG had not obtained permission to "disseminate it widely." Id.

As mentioned earlier, though, NAAG highlighted this 81.3 million dollar figure in urging Congress to enact the PLRA. In addition, PLRA supporters in Congress repeatedly invoked this figure as the legislation moved through Congress. See, e.g., 141 CoNG. REc. S14,316 (1995) (statement of Sen. Abraham); id. at S14,413 (statement of Sen. Dole); id. at S14,626 (statement of Sen. Dole); id. at S1S,296 (statement of Sen. Abraham); id. at S19,113 (statement of Sen. Kyl).

170. See, e.g., Boivin v. Black, 225 F.3d 36, 45-46 (1st Cir. 2000); Madrid v. Gomez, 190 F.3d 990, 996 (9th Cir. 1999).

171. Boivin, 225 F.3d at 45 .

172. Id.

173. Id.

174. See, e.g., Madrid, 190 F.3d at 996 (concluding, rather elliptically, that the hourly-rate restriction may reduce prisoners' filing of frivolous lawsuits because prisoners are potentially more prone to file such suits).

175. According to the Supreme Court, a claim is frivolous if it has no "arguable basis either in law or in fact." Neitzke v. Williams, 490 U.S. 319, 325 (1989). 
litigating frivolous claims. ${ }^{176}$ Courts can award only prevailing parties attorney's fees under $\S 1988$, and parties do not prevail on frivolous claims.

Even if a prisoner whose attorney files a frivolous claim brings enough other meritorious claims to be considered the prevailing party, the attorney will not receive recompense in the fee award for any work related to the frivolous claim. The PLRA now specifically restricts prisoners' reimbursable attorney's fees to those incurred in proving "an actual violation" of a right protected by a statute triggering a fee award under $\S 1988,{ }^{177}$ excluding frivolous claims.

Attorneys are aware not only that the court will refuse to order defendants to reimburse them for the fees incurred in bringing a frivolous claim, but that the court may penalize them for doing so. Under Rule 11 of the Federal Rules of Civil Procedure, courts may impose a range of sanctions on attorneys who bring frivolous claims on behalf of their clients. ${ }^{178}$ These sanctions may include monetary penalties, such as payment of the defendant's attorney's fees and litigation expenses. ${ }^{179}$

The Rule 11 sanctions are not confined to attorneys who file frivolous claims, but extend also to those who "advocat[e]" such claims. ${ }^{180}$ This fact further undermines the argument that the interest in curbing frivolous prisoners' claims justifies the differential treatment of prisoners and nonprisoners under $\S 1988$. The exact opposite is true: Encouraging attorneys to represent prisoners with civil rights claims by promising them reasonable compensation for their work if they prevail will actually reduce both the initial filing, and the continued pursuit of, frivolous claims by prisoners. The attorneys will not append such noncompensable and sanction-inviting claims to complaints they draft, and if the attorneys assume representation of a prisoner after the original complaint was already filed, the attorney will have a financial incentive and an ethical responsibility ${ }^{181}$ to file an amended complaint out of which the attorney has culled any frivolous claims.

Two Supreme Court cases, Rinaldi v. Yeager ${ }^{182}$ and Lindsey v. Normet, ${ }^{183}$ further buttress the conclusion that the PLRA's fee restrictions are not rationally related to the concededly legitimate interest in reducing

176. See 42 U.S.C. $\$ 1988$ (b) (confining the award of attorney's fees to "prevailing part[ies]" and limiting awarded fees to those that are "reasonable").

177. 42 U.S.C. $\$ 1997 \mathrm{e}$ (d)(1)(A) (Supp. IV 1999); see also supra text accompanying notes $47-48$.

178. FED. R. CIV. P. 11(b)(2)-(3), (c)(2).

179. FED. R. CIV. P. 11(c)(2).

180. FED. R. Civ. P. 11(b).

181. See Model Rules Of Prof'l Conduct R. 3.1 (1983) ("A lawyer shall not bring or defend a proceeding, or assert or controvert an issue therein, unless there is a basis for doing so that is not frivolous, which includes a good faith argument for an extension, modification or reversal of existing law.").

182. 384 U.S. 305 (1966).

183. 405 U.S. 56 (1972). 
prisoners' frivolous lawsuits. The plaintiff in Rinaldi was a prisoner who filed a $\$ 1983$ suit to enjoin the enforcement of a New Jersey statute under which prisoners who unsuccessfully appealed their convictions were required to reimburse the county for the cost of their transcripts used on appeal. ${ }^{184}$ The statute, though, did not require other convicted persons, such as those sentenced to probation or on whom a fine had been imposed, to reimburse the county for the costs of their transcripts. ${ }^{185}$

The Supreme Court held that this discordant treatment of prisoners violated their constitutional right to be afforded the equal protection of the law. ${ }^{186}$ The Court dismissed the defendants' argument that the classification created by the law rationally furthered the interest in discouraging frivolous appeals. ${ }^{187}$ The Court first noted that the reimbursement requirement would thwart not only the filing of some frivolous appeals, but also many nonfrivolous appeals. ${ }^{188}$ In the nomenclature of equal protection law, the Court thus signaled that the reimbursement statute was overinclusive, adversely affecting many individuals in cases where application of the statute would not further its purposes. The Court also observed that the reimbursement statute was underinclusive, insulating nonprisoners who brought frivolous appeals from the reimbursement requirement. ${ }^{189}$

The coinbined effect of the reimbursement statute's over- and underinclusiveness was to deter some prisoners with nonfrivolous claims from appealing their convictions while leaving unimpeded the filing of frivolous appeals by nonprisoners. The Supreme Court therefore concluded that the state had drawn an "unreasoned distinction" between prisoners and nonprisoners when atteinpting to further its objective of deterring frivolous appeals. ${ }^{190}$

If a transcript-payment requireinent confined to unsuccessful prisoner litigants is unconstitutional, as the Supreme Court held in Rinaldi, then the case against the constitutionality of the fee-cap and hourly-rate restrictions applicable to prisoners only is even stronger. In Rinaldi, the statute the Supreme Court struck down on equal protection grounds clearly had an impact, consistent with the statute's purpose, on the individuals targeted by the statute: prisoners filing frivolous appeals. These individuals had to reimburse the county for the costs of their transcripts. At the same time, the Court's conclusion that the reimbursement statute would adversely affect prisoners with nonfrivolous claims, although logical, was somewhat speculative; it was not grounded on research or any documented facts.

184. 384 U.S. at 305-08.

185. Id. at 308 .

186. Id.

187. Id. at 310 .

188. Id.

189. Id.

190. Id. 
By contrast, the PLRA's fee-cap and hourly-rate restrictions reflect the reverse situation: The argument that the fee restrictions will have an impact on the individuals allegedly targeted by the restrictions, prisoners filing frivolous civil rights claims, is not only speculative, but fanciful. ${ }^{191}$ In addition, the conclusion that the fee restrictions will adversely affect prisoners with meritorious claims is founded not on whimsy, but on fact, since the prisoners subject to these restrictions were prevailing plaintiffs whose claims were, by definition, meritorious.

Lindsey v. Normet ${ }^{192}$ also demonstrates the invalidity of the PLRA's fee restrictions. In that case, the Supreme Court addressed the constitutionality of Oregon's Forcible Entry and Wrongful Detainer Statute, under which landlords could oust tenants who wrongfully possessed their property. ${ }^{193}$ One of the statute's contested provisions stated that a defendant who lost a suit brought under that statute had to file a "double bond" as a condition of bringing an appeal. ${ }^{194}$ Specifically, the defendant had to obtain security from two sureties for the payment to the landlord of twice the property's rental value from the date the landlord brought the lawsuit until the date the trial court entered a final judgment for the landlord. ${ }^{195}$ If the appellate court then affirmed the lower court's judgment, the double bond was forfeited and remitted to the landlord. ${ }^{196}$

The tenants who challenged the constitutionality of the double-bond requirement in Lindsey argued that it violated their right to the equal protection of the law, since no other civil litigants taking an appeal in Oregon were subject to this requirement. ${ }^{197}$ The Oregon Supreme Court, though, had postulated a legitimate purpose for the double-bond requirement: to deter tenants from bringing frivolous appeals in forcible-entryand-detainer actions. ${ }^{198}$ Without such a double bond, tenants would have no incentive to refrain from filing frivolous appeals, since they could retain possession of the contested property pending the appeal and then simply pay the rent they owed when the appellate court rendered its adverse decision. ${ }^{199}$

Although the Court recoguized the legitimacy of the governmental interest in deterring frivolous appeals, it found no reasonable relationship between the double-bond requirement and the goal of discouraging

\footnotetext{
191. See supra text accompanying notes 174-181.

192. 405 U.S. 56 (1972).

193. Id. at 63 .

194. Id. at 63-64. This double bond was in addition to the "undertaking" that civil litigants taking an appeal in Oregon had to give, with a surety, to cover the costs of any monetary relief awarded against the appellant on appeal. $I d$. at 75-76.

195. Id.

196. Id. at 76 .

197. Id. at 74 .

198. Id. at 76 .

199. Id.
} 
frivolous appeals or any other legitimate governmental objective. ${ }^{200}$ As in Rinaldi, the Court focused on what it considered the haphazard lines drawn by the legislature. The Court noted that the double-bond requirement would have no impact on tenants whose appeals were frivolous but who could afford to pay the double bond, ${ }^{201}$ while it would effectively bar tenants unable to pay the double bond from bringing appeals on which they could prevail. ${ }^{202}$ The Supreme Court concluded, in short, that the distinction the Oregon legislature had drawn between tenants and other litigants bringing appeals was wholly arbitrary. ${ }^{203}$

The link between the PLRA's fee restrictions and the interest in curbing frivolous litigation is even weaker than the link the Supreme Court deemed too tenuous in Lindsey. It is likely that the prospect of paying rental payments twice their normal size would dissuade many tenants from bringing frivolous appeals to delay their mevitable ouster from the property. By contrast, saying that the restrictions on the attorney's fees inmates can recover under $\S 1988$ for meritorious claims will have an effect on prisoners' filing of frivolous lawsuits and appeals is to engage in fanciful imagining, perhaps rooted in thinly veiled anti-prisoner animus.

At least one court has opined, ${ }^{204}$ however, that the double-bond requirement deemed unconstitutional in Lindsey is distinguishable from the PLRA's fee restrictions because the double-bond requirement erected a "substantial barrier" to court access to which no other person bringing an appeal was subject. ${ }^{205}$ By contrast, the PLRA fee restrictions simply remove from prisoners part, though not all, of a benefit bestowed on civil litigants who prevail in the types of lawsuits that trigger a fee award under $\S 1988^{206}$

The distinction this argument carves, however, between governmenterected barriers or burdens, on the one hand, and government-withheld benefits, on the other, does not validate the PLRA's fee restrictions. First, there is no plausible basis for concluding that the equal protection guarantee forbids the arbitrary and irrational imposition of disparate burdens on similarly situated individuals but condones arbitrary and irrational

\footnotetext{
200. Id.

201. Id. at 78 .

202. Id. at 79 .

203. Id.

204. Boivin v. Black, 225 F.3d 36, 45 (1st Cir. 2000). In distinguishing Lindsey, the First Circuit Court of Appeals in Boivin stated:

$[\mathrm{U}]$ nlike the double-bond requirement, the cap on attomey's fees is not a barrier to court access, but a limitation on relief: the double-bond requirement operated directly to bar appeals by individuals who could not afford the extra cost, whereas the fee cap only affects Id. how claims are presented and does not preclude any prisoner from actually bringing a claim.

205. In Lindsey, the Supreme Court observed that the double-bond requirement erected a "substantial barrier to appeal." 405 U.S. at 79.

206. Boivin, 225 F.3d at 45.
} 
differences in the extension of benefits to them. The patent unconstitutionality of any law extending welfare benefits to people of one race, but not another, confirms the fallacy of cordoning off the allocation of so-called "benefits" from equal protection scrutiny. ${ }^{207}$

Second, the purported distinction between the imposition of burdens and the extension of benefits is, as Rinaldi demonstrates, chimerical. ${ }^{208}$ The statute the Supreme Court found unconstitutional in that case could be aptly described either as imposing disparate burdens on similarly situated individuals or as extending differing benefits to them. It could be argued that requiring convicted prisoners, but not others, to reimburse a county for the costs of their transcripts foists a disparate fiscal burden on prisoners. But it could equally be said that paying the costs of the transcripts for all indigent convicted persons except those sentenced to prison deprives prisoners of a financial benefit accorded others. Thus, whether disparity in treatment involves the imposition of a burden or the withholding of a benefit is a semantical question, not one of constitutional import. ${ }^{209}$

Third, Rinaldi confirms that the distinction between overt front-end barriers to court access and covert back-end barriers like the PLRA's fee restrictions is irrelevant for equal protection purposes. The double-bond requirement the Supreme Court held unconstitutional in Lindsey was a transparent front-end barrier: a defendant appealing a judgment in a forcible-entry-and-detainer action had to post the double bond as a condition of gaining access to the appellate court. By contrast, the convicted prisoners in Rinaldi whom the Supreme Court said were unconstitutionally discriminated against did not have to meet any preconditions before filing an appeal. Only at the end of the appellate process and only when the appeal had been unsuccessful did the prisoner have to reimburse the county for the costs of his or her transcript. Nonetheless, the Supreme Court held that the differential treatment of prisoners contravened their right to the equal protection of the law, because there was an insufficient link between this differential treatment and the asserted justifications for it. . $^{210}$

That the PLRA's $150 \%$ fee cap and hourly-rate restrictions do not, unlike the reimbursement statute in Rinaldi, levy a direct charge on prisoners is also irrelevant from an equal protection standpoint. In both Rinaldi and Lindsey, the Court emphasized the practical effect of the statutes that

207. Cf. Lewis v. Grinker, 111 F. Supp. 2d 142, 185-86 (E.D.N.Y. 2000) (striking down, on equal protection grounds, a restriction on certain pregnant aliens' eligibility for Medicaid benefits covering routine prenatal care).

208. See supra text accompanying notes 184-190.

209. Compare James v. Strange, 407 U.S. 128 (1972), discussed infra at text accompanying notes 242-249, in which the unconstitutional dissimilar treatment of civil debtors by the state could be categorized as either the disparate imposition of a burden (higher debt-repayment requirements) on one type of debtor, or as the disparate dispensation of benefits (protective exemptions that diminished these payment requirements).

210. Rinaldi, 384 U.S. at 309. 
subjected litigants to differential treatment, rather than their precise form. For example, in both cases, the Supreme Court focused on the impact the challenged statutes would have on the bringing of both frivolous and meritorious claims. ${ }^{211}$

Because attorneys, like other laborers, expect to be paid for their work, one practical consequence of the PLRA's fee restrictions is to require prisoners to pay the outstanding balance of their attorneys' fees (that is, those fees left unpaid by defendants because of the PLRA's restrictions). ${ }^{212}$ The PLRA's fee restrictions and the reimbursement statute ruled unconstitutional in Rinaldi have the same practical effect: prisoners have to pay a debt from which nonprisoners are absolved. The difference between the two statutes lies simply im the identity of the payee: the payee under the reimbursement statute was a county, while the payee of the fee balance left outstanding because of the PLRA's fee restrictions is typically a private attorney. This difference, from an equal protection perspective, is irrelevant. In sum, any argument that the governmental interest in curbing prisoners' filing of frivolous lawsuits is somehow rationally connected, or even remotely connected, to the PLRA's fee restrictions is itself wholly frivolous.

\section{b. Deterring the Filing of "Low-Value" Suits}

Perhaps because of the weaknesses in the argument that the PLRA's fee restrictions are reasonably related to the goal of curbing frivolous inmate lawsuits, courts have propounded another objective allegedly furthered by those restrictions: the deterrence of what the First Circuit Court of Appeals has described as "low-value" lawsuits. ${ }^{213}$ The supposition underlying this argument is that in the hope of garnering a substantial fee award, attorneys file claims for prisoners that, although meritorious, are "inconsequential," "marginal," or "trivial."214 Limiting attorneys" compensation in "low-value" lawsuits will therefore discourage them from clogging up the courts with such suits. ${ }^{215}$

The very sketchy legislative history of the PLRA's fee provisions suggests that the $150 \%$ fee cap was designed to deter the filing of lowvalue lawsuits. The House Report discussing the PLRA's general proportionality requirement, the requirement that attorney's fees awarded

211. See supra text accompanying notes 188-189, 201-202.

212. Another practical consequence is that the PLRA forecloses most indigent inmates from bringing or effectively litigating civil rights claims unless they can locate a lawyer willing to donate his or her labor at below market rates. For a discussion of inmates' general incompetence as litigators, see infra notes 264-266.

213. Boivin v. Black, 225 F.3d 36, 46 (1st Cir. 2000).

214. Hadix v. Johnson, 230 F.3d $840,844-45$ (6th Cir. 2000).

215. Id. at 845 . See also Boivin, 225 F.3d at 45 (arguing that the $150 \%$ fee cap "changes the odds and forces both lawyer and client, out of self-interest, to assess likely outcomes with greater care before filing a suit that, even if nominally successful, might leave them holding a nearly empty bag"). 
prevailing prisoners under $\S 1988$ be proportional to the relief ordered by the courts, observed that this requirement would "discourage burdensome litigation of insubstantial claims where the prisoner can establish a technical violation of a federal right but he suffered no real harm from the violation."216 This observation might equally apply to the fee cap, a more specific proportionality requirement applicable to judgments for monetary relief.

The threshold question in applying the rational basis test is whether the deterrence of "low-value" civil rights suits is a "legitimate" governmental objective. The contention that the fee cap furthers the legitimate interest in curtailing prisoners' filing of "low-value" constitutional claims rests on two assumptions: 1) that such claims exist; and 2) that the criterion for sifting out these claims is the size of the monetary judgment awarded a prisoner.

Even if it could be said that there are "low-value" and "insubstantial," though meritorious, constitutional claims, ${ }^{217}$ the theory that the size of the damages award necessarily reflects a claim's substantiality is without credence. In City of Riverside v. Rivera, ${ }^{218}$ the Supreme Court rejected this notion. ${ }^{219}$ In that case, the Court held that while the amount of damages a plaintiff had recovered was an appropriate factor to be considered by a court when calculating a fee award under $\S 1988,{ }^{220}$ it was not the only or the decisive factor. ${ }^{221}$ The Court rejected the idea that the amount of the damages award necessarily reflects the full value of a constitutional or civil right. ${ }^{222}$ "Unlike most private tort litigants," the Court stated, "a civil rights

216. H.R. REP. No. 104-21, at 28 (1995).

217. Some might consider the notion of "low-value" constitutional claims to be a classic oxymoron. The word "constitutional" means "of, relating to, or entering into the fundamental makeup of something," in other words, "essential." Merriam-Webster's Collegiate Dictionary 388 (deluxe ed. 1998); see also BLAcK's LAw Dictionary 282 (5th ed. 1979) (defining "constitution" as the "organic and fundamental law of a nation or state" or, more generally, "any fundamental or important law or edict"). Thus, a constitutional right could be viewed as one that the drafters of the Constitution considered of fundamental importance, one that it is essential to protect from governmental depredations. Under this perspective, Congress could not, through a legislative sleight of hand, transform that which, by definition, is of profound significance into a triviality.

218. 477 U.S. 561 (1986).

219. See supra text accompanying notes $88-90$.

220. 477 U.S. at 574.

221. Id. at 576-78. Consequently, a court can, in some circumstances, award attorney's fees under $\S 1988$ to a plaintiff awarded only nominal damages, despite the plaintiff's failure to prove that he or she was injured by a constitutional violation. Farrar v. Hobby, 506 U.S. 103, 114-15 (1992). In a concurring opinion in Farrar, Justice O'Connor, who provided the critical fifth vote in the Court's 5-4 decision, highlighted two of the factors that a court should consider when determining whether to award attorney's fees in such a case: the importance of the "legal issue" on which the plaintiff purportedly prevailed and the public benefits reaped from the lawsuit. Id. at 121-22 (O'Connor, J., concurring). Thus, according to Justice O'Connor, the nominal sum recovered by the plaintiff is only one of several "relevant indicia of success" factored into the fee-award decision. Id. at 122.

222. Id. at 574 . 
plaintiff seeks to vindicate important civil and constitutional rights that cannot be valued solely in inonetary terms." 223

The Supreme Court in City of Riverside also rejected the notion that the only beneficiary of a successful civil rights suit is the plaintiff. ${ }^{224}$ The Court noted that the public also reaps substantial benefits when constitutional and other civil rights are enforced, regardless of the amount of damages awarded a particular plaintiff. ${ }^{225}$ By highlighting the "public interest" in the vindication of civil rights, ${ }^{226}$ the Court acknowledged the inherent value to society of enforcing, rather than ignoring, the Constitution and civil rights laws. In addition, the Court noted that enforcing civil and constitutional rights deters future violations. ${ }^{227}$

The Supreme Court in City of Riverside was admittedly just engaging in a statutory analysis, determining whether Congress had intended $\S 1988$ to include a proportionality requirenent. The Court's insights about the assumptions underlying a proportionality requirement are also relevant, though, to the constitutional question whether the interest in curbing the filing of "low-value" constitutional claims, as measured by their pecuniary value, is legitimate. The answer to that question is that it is not. Automatically pegging lawsuits as "low value" when the damages awards are small has the practical effect of relegating certain constitutional rights to secondclass status. There are soine types of constitutional violations for which the damages awards will typically be low, particularly in cases brought by prisoners. For example, abridgements of the First Amendment right to religious freedom will seldom cause the kinds of tangible harm that will spawn sizeable damages awards. ${ }^{228}$ Yet the vindication of this right, like other constitutional rights, yields varied and inestinnable benefits, both for the aggrieved individuals and for the public. Thus, any asserted governmental interest in curtailing lawsuits because of the nonpecuniary nature of the constitutional rights they vindicate fails to meet the threshold requirement of legitimacy. 229

One possible rejoinder to the argument that the fee cap creates, in effect, a caste system of constitutional rights is that the constitutional rights

223. Id.

224. Id. ("[W]e reject the notion that a civil rights action for damages constitutes nothing more than a private tort suit benefiting only the individual plaintiffs whose rights were violated.").

225. Id. ("Regardless of the form of relief he actually obtains, a successful civil rights plaintiff often secures important social benefits that are not reflected in nominal or relatively small damages awards.").

226. Id.

227. Id. at 575 .

228. See, e.g., Nolley v. County of Erie, 802 F. Supp. 898, 910 (W.D.N.Y. 1992) (awarding HIVpositive inmate, who was denied access to group religious services for thirty-five weeks, ten dollars for each week, for a total of $\$ 350$ in compensatory relief).

229. In enacting $\$ 1988$, Congress rejected the notion that constitutional rights whose violation results in low monetary awards have diminished importance compared to other constitutional rights. See infra text accompanying note 300. 
whose violation will culminate in small damages awards can still be enforced because prisoners can seek and obtain injunctive relief to redress such violations. But often that is simply not true. For example, prisoners not permitted to exercise their religious rights at one prison may later be transferred to another prison after filing a lawsuit to enjoin the incursion on their religious rights. ${ }^{230}$ Unless the prisoners seek damages for the violation of their constitutional rights, ${ }^{231}$ the transfer will often moot their claim for injunctive relief. ${ }^{232}$ So the practical effect of the fee cap is that the enforceability of these rights whose violation would yield low damages awards is often in the hands of prison officials, some of whom may be the very persons responsible for these constitutional violations.

Even if the interest in deterring so-called low-value lawsuits were considered legitimate, the distinction the PLRA draws between prisoners and nonprisoners would have to be reasonably related to that interest in order to comport with equal protection requirements. And therein lies a problem.

There is no basis in the law or logic to suggest that prisoners' "lowvalue" suits are less important than nonprisoners' "low-value" suits. A case, for example, in which a jury awards a prisoner one hundred dollars in damages for a violation of his right to religious freedom has no less value than a case in which a jury awards a nonprisoner one hundred dollars for such a violation.

In fact, the opposite is more likely to be true; if we were to attempt to rank the two cases by their relative "value," the realities of inmate litigation suggest that the prisoner's case is primal. Juries are often disinclined to award convicted criminals damages, and even when they overcome this natural reticence, the damages they award prisoners are often low. ${ }^{233}$ Thus, a prisoner awarded one hundred dollars in damages is likely to have suffered much greater harm than a nonprisoner awarded the same amount. A statutory distinction resting on the comparative importance of "low-value" prisoners' claims and "low-value" nonprisoners' claims is therefore specious and will not justify application of the $150 \%$ fee cap to prisoners alone.

230. See, e.g., Young v. Lane, 922 F.2d 370, 371, 373 (7th Cir. 1991) (holding that the transfer of Jewish inmates to another prison mooted their claims for injunctive relief stemming from the defendants' alleged failure to schedule religious services for Jewish inmates and to take other steps enabling them to practice their religion).

231. See Boag v. MacDougall, 454 U.S. 364 (1982) (holding that prisoner's claim for damages survived his transfer to another prison).

232. See, e.g., Henderson v. Sheahan, 196 F.3d 839, 843 n.1 (7th Cir. 1999) (holding that a pretrial detainee's claim for injunctive relief to abate his exposure to second-hand smoke was mooted by his transfer to a state prison), cert. denied 120 S. Ct. 2691 (2000).

233. John Boston \& Daniel E. Manville, Prisoners' Self-Help Litigation Manual, at $481,483 \&$ n.660 (3d ed. 1995). 
The only other possible hypothesis for distinguishing between the two types of litigants is that attorneys are more inclined to file "low-value" lawsuits for prisoners than for nonprisoners, necessitating or supporting the adoption of special disincentives to discourage the filing of such suits for prisoners. But the opposite is, once again, more likely to be true. Attorneys, it would seem, would be especially reluctant to represent prisoners in "lowvalue" lawsuits because of the barriers that they must overcome to prevail in such lawsuits.

Those barriers are both legal and factual in nature. On the legal end, courts apply the Constitution differently to prisoners out of a concern for preserving institutional security and upholding penological objectives. ${ }^{234}$ The limited scope of prisoners' constitutional rights makes it much more difficult for them to prevail on constitutional claims. ${ }^{235}$ And unless a prisoner prevails in court, no fee award will be forthcoming.

Significant practical obstacles also stand in the way of the favorable judgnients for prisoners on which fee awards piggyback. As mentioned earlier, juries harbor biases against prisoners, making juries indisposed to return verdicts awarding prisoners money damages. In addition, because correctional facilities are closed institutions to which attorneys have only limited access, attorneys representing prisoners face special hindrances when investigating the facts of a case and locating the evidence needed to prove a meritorious claim. The distance between the attorney's office and the prison where his or her client is confined, as well as the distance between the office and other prisons to which inmate-witnesses may have been transferred, compound the problems that an attorney confronts when investigating the facts of a case and tracking down evidence corroborating the prisoner-plaintiff's claim. ${ }^{236}$

In sum, the illegitimate interest in thwarting the filing of constitutional claims cannot be legitimized by simply typecasting certain claims as "low value." Courts, though, may feel compelled by the laxity of the rational basis test to find that quelling "low-value" constitutional claims is a legitimate governmental interest and that low monetary value is a nonarbitrary, if not accurate, proxy for low public value. Even then, this governmental interest would not validate the PLRA's fee restrictions. The restrictions would still violate the requirements of equal protection, because the

234. See, e.g., Turner v. Safley, 482 U.S. 78, 93 (1987) (holding that a ban on inmate-to-inmate correspondence did not violate inmates' First Amendment rights because the ban was reasonably related to the interest in preserving institutional security).

235. See, e.g., Bell v. Wolfish, 441 U.S. 520, 558, 560 (1979) (holding that visual body cavity searches of pretrial detainees need not be grounded on probable cause); $c f$. Maryland v. Buie, 494 U.S. 325, 331 (1990) (holding that houses generally cannot be searched without a warrant supported by probable cause).

236. See, e.g., Procunier v. Martinez, 416 U.S. 396, 420 (1974) (observing that "[t]he remoteness of many California penal institutions makes a personal visit to an inmate client a time-consuming undertaking"). 
interest does not justify the distinction drawn between prisoners who bring meritorious civil rights claims and nonprisoners who bring such claims.

\section{c. Saving Taxpayers' Money}

Another interest proffered in defense of the constitutionality of the PLRA's fee restrictions is the interest in limiting the public funds expended on prisoners' attorney's fees. ${ }^{237}$ This interest in conserving public resources is undoubtedly a legitimate one, and the PLRA's fee restrictions will further this interest both directly and indirectly. The fee cap and the hourlyrate restriction will directly limit the amount of money drawn from public coffers to pay attorney's fees. In addition, the prospect of a fee recovery that does not compensate an attorney for the market value of his or her work and, in the case of the fee cap, will often reimburse the attorney at a subminimum-wage rate, will likely dissuade many attorneys from representing prisoners. As a result, taxpayers' money will, at least in the short term, be saved. ${ }^{238}$

The legitimacy of the interest in conserving public funds and the fact that the fee restrictions would further that interest, however, does not automatically validate the PLRA's fee restrictions from an equal protection standpoint. Otherwise, Congress could constitutionally enact a statute curtailing the attorney's fees awarded under $\S 1988$ to prevailing plaintiffs with brown hair or with blue eyes. Such a statute would save public money, but it would do so by arbitrarily and capriciously singling out a group of individuals for disparate treatment. It is this very arbitrariness and capriciousness in statutory line-drawing that the equal protection guarantee forbids.

A number of Supreme Court cases confirm that governments cannot balance their budgets by invidiously discriminating against disfavored groups. For example, in Rinaldi v. Yeager, ${ }^{239}$ the Supreme Court held that the government's fiscal interest would not justify requiring prisoners, but not others, to reimburse counties for the costs of their transcripts on unsuccessful appeals. ${ }^{240}$ According to the Court, prisoners' status as prisoners simply had no bearing on, and no relationship to, the government's financial objective. ${ }^{241}$

The Supreme Court's decision in James v. Strange $e^{242}$ also illustrates that budgetary concerns do not trump the Constitution's equal protection guarantee. That case involved the constitutionality of a state recoupment

\footnotetext{
237. See, e.g., Hadix v. Johnson, 230 F.3d 840, 845-46 (6th Cir. 2000).

238. But see infra text accompanying notes 292-293 (discussing $\S 1988$ 's premise that the recovery of attorney's fees is a cost-effective means of enforcing civil rights).

239. 384 U.S. 305 (1966); see also supra text accompanying notes 184-190.

240. Id. at $309-10$.

241. Id.

242. 407 U.S. 128 (1972).
} 
statute under which indigent defendants represented by appointed counsel in criminal cases were obliged to reimburse the state for their legal defense fees. ${ }^{243}$ The equal protection challenge to the statute arose from the fact that it did not extend to indigent defendants the same protective exemptions afforded other civil debtors. ${ }^{244}$ For example, while the state limited the amount of other debtors' earnings subject to garnishment, the recoupment statute removed this protective exemption from indigent defendants. ${ }^{245}$

The Supreme Court held that withholding the benefits of the protective exemptions from indigent criminal defendants constituted the kind of invidious discrimination proscribed by the equal protection clause. ${ }^{246}$ The Court acknowledged the value of recoupment statutes in replenishing the coffers of state and local governments operating under tight budgets. ${ }^{247}$ Additionally, the Court recognized that increases in criminal-case filings and in the number of indigent defendants entitled to appointed counsel placed augmented financial burdens on states and localities. ${ }^{248}$ But the Court remonstrated that the state recoupment law could still meet its fiscal objective without subjecting indigent defendants to such uneven treatment. ${ }^{249}$

The question raised by the PLRA's fee restrictions then is not whether or not they save governments money, but whether the distinction the fee restrictions draw between prisoners and nonprisoners is reasonably related to this purported fiscal goal. Put in other terms: 1s there a "rational reason to spare" nonprisoners "an equal burden," ${ }^{250}$ the burden of either locating an attorney willing to forgo adequate compensation for his or her services, ${ }^{251}$ litigating the case pro se if such an attorney cannot be found, or paying the accrued attorney's fees left unpaid because of the fee restrictions?

243. Id. at 128 .

244. Id. at 131 .

245. Id. at 135-36.

246. Id. at $141-42$.

247. Id. at 141 .

248. Id. at $141-42$.

249. Id.

250. Williams v. Vermont, 472 U.S. 14,25 (1985).

251. This burden may be greater for prisoners than nonprisoners. As mentioned earlier, see supra text accompanying notes 234-235, lawyers may be particularly reluctant to represent prisoners because it is so difficult for prisoners to prevail in civil rights suits. In addition, prisoners' physical confinement likely makes it more difficult for them to identify and induce attorneys to represent them. Prisoners are often confined in prisons located far away from the urban areas in which most attorneys work, and prisoners may not have access to the telephone or other directories that would enable them to identify attomeys to be contacted regarding potential representation. Even when prisoners can identify the attomeys to contact, prisoners do not normally have the opportunity nonprisoners have to meet face to face with the attorneys when tendering their request for representation, thereby diminishing their chances of persuading an attorney to take their case. 
It is difficult to envision how this question could be answered in the affirmative. Nonprisoners' lawsuits place substantial burdens on courts, and members of Congress acknowledged as much as the PLRA moved through Congress. ${ }^{252}$ Those lawsuits also impose significant financial burdens on governmental defendants and the public treasury. These burdens stem from the fees and costs incurred by the defendants litigating the cases, the money expended complying with courts' remedial orders, and the payment of prevailing plaintiffs' attorney's fees for which the defendants are responsible under $\S 1988$ and other fee-award statutes.

The Administrative Office of the United States Courts, which collects statistics on cases filed in federal court, does not compile statistics on the amount of attorney's fees awarded prisoners and nonprisoners under $\S 1988 .^{253}$ However, even if it could be established that prisoners recover more attorney's fees under $\S 1988$ than nonprisoners, that fact alone would not constitute the requisite "rational basis" for subjecting prisoners, but not nonprisoners, to fee restrictions.

1t must be remembered that prisoners can recover attorney's fees under $\S 1988$ only when they prevail in their lawsuits. In addition, courts can award prevailing prisoner-plaintiffs only "reasonable" attorney's fees. ${ }^{254}$ Thus, if it were true that governments pay more in attorney's fees under $\S 1988$ to prisoners than nonprisoners, one or more of five reasons would account for this difference: I) prisoner-plaintiffs establish more often than nonprisoners that their constitutional or other civil rights were violated;2) defendants sued by prisoners resist settling these cases more than defendants in nonprisoners' cases; 3) defendants in lawsuits in which inmates have prevailed drag their heels in complying with the courts' reinedial orders, thus driving up attorney's hours and fees; ${ }^{255}$ 4) litigation is prolonged by legislatures' refusal to allocate the funds correctional officials have requested to come into compliance with courts' orders; or 5) prisoners' civil rights cases are more complex and difficult to litigate, necessitating the incursion of higher attorney's fees.

252. See, e.g., 141 CoNG. REc. S7526 (1995) (statement of Senator Kyl) ("[T]he judicial system . . . is already overburdened by increases in nonprisoner litigation."); $i d$. at \$14413 (statement Sen. Dole) ("Unfortunately, the litigation explosion now plaguing our country does not stop at the prison gate.").

253. Facsimile from Gwendolyn W. Coleman, Technical Information Specialist, Admimistrative Office of the United States Courts, to Lynn S. Branham (Oct. 3, 2000) (on file with author).

254. 42 U.S.C. $\$ 1988(b)$ (1994).

255. Courts have, in the past, complained of correctional officials' obstructive litigation tactics. See, e.g., Glover v. Johnson, 934 F.2d 703 (6th Cir. 1991), where the court stated:

The history of this case shows a consistent and persistent pattern of obfuscation, hypertechnical objections, delay, and litigation by exhaustion on the part of the defendants to avoid compliance with the letter and the spirit of the district court's orders. The plaintiff class has struggled for eleven years to achieve the simple objectives of equal protection under the law generally, and equality of opportunity specifically.

Id. at 715 . 
If any of the first four reasons accounted for the hypothetically greater amount of money governments spend on prisoners' attorney's fees awarded under $\$ 1988$, the financial burden of paying those fees would clearly not justify placing special fee restrictions on prisoners. In other words, the interest in saving money implicated in any of these four scenarios is illegitimate from an equal-protection standpoint. To hold otherwise would give credence to the spurious argument that Congress can subject prisoners to fee restrictions to which nonprisoners are not subject because government officials violate prisoners' rights more frequently than those of nonprisoners and because defendants sued by prisoners or legislatures are particularly recalcitrant to make amends for illegal actions.

The remaining reason why the total attorney's fees awarded prisoners under $\$ 1988$ might be higher, if indeed they are higher, than the total fees awarded nonprisoners is the possible greater difficulty of litigating prisoners' cases. The difficulty of litigating these kinds of cases is, however, a fact over which prisoners have no control, but one over which defendants exercise at least a modicum of control. For example, correctional officials can refrain from transferring inmate-witnesses to more distant locations, making it more difficult and time-consuming for the attorneys to obtain information from these witnesses. It would therefore be odd and, in the language of equal protection law, "irrational" to treat prisoners worse than nonprisoners under $\$ 1988$ because prisoners face greater difficulties litigating and prevailing on their cases. This is particularly true when correctional officials can mampulate the circumstances contributing to the complexity of inunate litigation.

When assessing whether restricting the attorney's fees awarded prisoners, but not nonprisoners, is rationally connected to the goal of conserving public funds, it is important to remember that government officials have significant control over the size of those fee avvards. First, government officials can settle, early on, cases in which prisoners have asserted meritorious claims. As the Supreme Court observed in City of Riverside, "The government cannot litigate tenaciously and then be heard to complain about the time necessarily spent by the plaintiff in response."'256

Second, government officials can promptly implement settlement agreements and, in adjudicated cases, expeditiously comply with courts' remedial orders. If correctional officials and legislatures move with dispatch to bring correctional facilities into compliance with legal requirements, they can substantially reduce the amount of attorney's fees incurred by prisoners during the remedial stage of the litigation.

Third, defendants sued by a prisoner can cap the plaintiff's attorney's fees for which they may be held liable by tendering to the plaintiff a

256. City of Riverside v. Rivera, 477 U.S. 561, 580-81 n.11 (1986) (quoting Copeland v. Marshall, 641 F.2d 880, 904 (1980)). 
reasonable offer of judgment under Rule 68 of the Federal Rules of Civil Procedure. If the plaintiff does not accept the offer and obtains a judgment less "favorable" than the relief embodied in the offer of judgment, the court cannot award the plaintiff costs, including attorney's fees, ${ }^{257}$ incurred after the offer was made. ${ }^{258}$

One of the ironies of the asserted fiscal rationale for the disparate treatment of prisoners under $\S 1988$ is that correctional officials actually have a greater ability than do officials sued by nonprisoners to avoid a fee award completely. Prisoners must exhaust their administrative remedies before filing a complaint contesting the legality of the conditions of their confinement. ${ }^{259}$ By contrast, nonprisoners need not even notify governmental officials before filing a civil rights suit against them. ${ }^{260}$ Consequently, correctional officials have the opportunity, if they construct their grievance processes appropriately, ${ }^{261}$ to remedy violations of prisoners' rights and completely avert the filing of lawsuits that may trigger fee awards under $\S 1988$.

In summary, although saving taxpayer money is a legitimate governmental interest, the PLRA's restrictions on attorney's fees are not a rational means to that end. Those restrictions therefore constitute the invidious discrimination proscribed by the Constitution's equal protection guarantee.

\section{d. Curbing Federal-Court Intervention in Correctional Operations}

The final interest that has been cited in support of the constitutionality of the PLRA's fee cap and hourly-rate restrictions is the interest in curbing federal-court intervention in correctional operations. ${ }^{262}$ Those invoking this interest argue that inmate litigation places extensive burdens on correctional operations that go well beyond the fiscal burdens that attend such litigation. For example, lawsuits sap the time of correctional officials, who must collect sometimes voluminous amounts of information in response to discovery requests of prisoners' attorneys, attend depositions, court hearings, and trials, and perform myriad other litigation-related tasks. In

257. Marek v. Chesny, 473 U.S. 1, 9 (1985) (concluding that cost shifting under Rule 68 includes attorney's fees recoverable under $\S 1988)$.

258. FED. R. CIV. P. 68.

259. 42 U.S.C. $\$ 1997 \mathrm{e}$ (a) (Supp. IV 1999); see also supra text accompanying note 31.

260. See Felder v. Casey, 487 U.S. 131, 134 (1988) (holding that a state statute requiring an individual, as a precondition to filing a lawsuit against a governmental official or entity, to notify prospective defendants of a claim 120 days after the incident giving rise to the claim cannot be applied to plaintiffs bringing $\S 1983$ actions).

261. For recommendations regarding how correctional officials can devise grievance systems to avert inmate litigation, see BRANHAM, supra note 169, at 83-88 (1997); see also Lynn S. Branham, The Prison Litigation Reform Act's Enigmatic Exhaustion Requirement: What It Means and What Congress, Courts, and Correetional Officials Can Learn From It, 86 CORNELL L. REv. 483, 521-27 (2001).

262. E.g., Hadix v. Johnson, 230 F.3d 840, 844 (6th Cir. 2000). 
addition, according to the fee restrictions' proponents, ${ }^{263}$ litigation causes friction between staff and inmates and adversely affects staff morale.

In determining whether the interest invoked is both legitimate and rationally connected to its purported objective, one must ask: What would happen if the fee restrictions achieved the touted objective of discouraging attorneys from representing inmates? The answer is that some prisoners would probably proceed to represent themselves in the litigation, while others, unable or unwilling to tackle the complexities of litigation on their own, would never bring their constitutional or civil rights claims to court.

For prisoners who would choose to represent themselves, the connection between the interest in reducing litigation burdens and the means employed to effectuate that objective is, in the words of equal protection law, irrational. Replacing attorneys with prisoners to handle the litigation would not and could not diminish the burdens of litigation on correctional operations. To the contrary, courts and correctional officials have long lamented prisoners' incompetence as litigators. ${ }^{264}$ Prisoners, unschooled in the law and often functionally illiterate, ${ }^{265}$ typically file documents that are difficult for correctional officials and their attorneys to decipher and address. ${ }^{266}$ Processing these prisoner-prepared documents is also burdensome on courts.

Removing attorneys as the buffer between their clients and correctional officials would also likely exacerbate, not diminish, the tension between prisoners and the correctional officials whoin they have sued. ${ }^{267}$ For example, if prisoners, rather than attorneys, took correctional officials'

263. See Wolff v. Moore, 104 F. Supp. 2d 892, 901 (S.D. Ohio 2000), vacated by 234 F.3d 1271 (6th Cir. 2000).

264. BRANHAM, supra note 169 , at 36-37.

265. In 1994, the National Center for Education Statistics reported that seven out of ten inmates perform at the lowest literacy levels. KarL O. Haigler ET AL., U.S. DePT. OF Educ., Literacy Behind Prison Walls: Profiles of the Prison Population from the National, adult LITERACY SuRveY xviii, 17-19 (1994). Most prisoners therefore have problems "integrat[ing] or synthesiz[ing] information from complex or lengthy texts," skills needed to litigate a case effectively. Id.

266. See Johnson v. Avery, 393 U.S. 483, 488 (1969) ("It is indisputable that prison 'writ writers' like petitioner are sometimes a menace to prison discipline and that their petitions are often so unskillful as to be a burden on the courts which receive them."). In fact, supporters of the PLRA in Congress decried the burdens courts face because of "jailhouse Iawyers," prisoners who assist other prisoners in litigating their cases. See, e.g., 141 CoNo. REc. SI4,628 (1995) (statement of Sen. Thurmond) ("[Prisoners] have tied up the courts with their jailhouse antics for too long. ... We need to put a stop to these jailhouse lawyers who are making a mockery of our criminal justice system.").

267. Attorneys' representation of prisoners can also avert security problems that ensue when prisoners represent themselves or other prisoners. For example, a jailhouse lawyer may extort favors from a prisoner, including sexual services, as a condition of representing the prisoner. Johnson, 393 U.S. at 499-500 (White, J., dissenting). The prisoner-litigant's refusal or failure to meet the demands of the jailhouse lawyer may then lead to violence. $I d$. at 500 . In addition, providing inmates representing themselves with access to a prison law library may facilitate the passage of contraband between prisoners. See BraNHAM, supra note 169 , at 37. 
depositions, it would be more, not less, likely that the deposition-taking process would be fraught with animosity. ${ }^{268}$

Similarly, placing inmates in situations where they are in more direct conflict with correctional staff could hardly be considered a staff moralebooster, except to the extent that staff would be more confldent that inmates could not prevail on meritorious claims. Infusing staff with good feelings because they know that they can now violate inmates' rights with relative impunity, however, scarcely qualifies as a valid reason for denying prisoners with meritorious claims the benefits afforded nonprisoners under $\S 1988$.

The other expected outcome that would follow from discouraging attorneys from representing prisoners with meritorious claims is that some of those claims will never be brought to court. Obviously, a claim that is never filed cannot have any adverse operational effects. ${ }^{269}$ But parsing through the argument of correctional officials ${ }^{270}$ stemming from this practical reality reveals its untenability as a basis for upholding the constitutionality of the PLRA's fee restrictions.

Essentially, correctional officials are arguing that it is constitutional to treat prisoners differently under $\S 1988$ than nonprisoners because when prisoners prevail in their lawsuits, correctional officials have to modify their practices; they cannot continue to run their prisons as they have im the past. This assertion is, however, a classic non sequitur. The illegitinate desire to persist in violating prisoners' constitutional rights because correctional officials would face challenges during the process of bringing their facilities into compliance with constitutional requirements cannot, by definition, legitimize the disparate treatment of prisoners under $\S 1988$.

268. Cf. Wolff v. McDonnell, 418 U.S. 539, 567 (1974) (observing that if prisoners had a right to confront and cross-examine adverse witnesses during prison disciplinary hearings, "there would be considerable potential for havoc inside the prison walls").

269. Of course, a claim that is never filed can also have no positive operational effects. Claims not filed because of prisoners' inability to locate competent counsel willing to work at reduced rates may lead to the perpetuation of illegal conditions and practices that endanger staff and inmates alike and that impede inmate rehabilitation.

270. Hadix v. Johnson, 230 F.3d 840, 844 (6th Cir. 2000). 


\section{IV}

\section{The Practical Impact of the PLRA's Fee Restrictions ${ }^{271}$}

To say that the PLRA's fee restrictions affect prisoners, but not nonprisoners, masks the full arbitrariness of this legislative classification. Several concrete examples illustrate more clearly the vagarious dividing line the PLRA has drawn between prevailing parties who will be fully compensated for their attorney's services under $\S 1988$ and those who will be reimbursed only a partial, and sometimes minuscule, amount for those services.

Assume first that a man is beaten and injured by a police officer. The man, who is never incarcerated in a correctional facility, prevails in a $\S 1983$ suit against the police officer. Assume next that a prisoner is beaten by a correctional officer, sustaining the same injuries as those inflicted on the police victim. The prisoner, while still confined in prison, files a successful $\S 1983$ suit against the correctional officer. Even though the prisoner and the police victim have suffered constitutional violations identical in their severity, the prisoner, unlike the police victim, is subject to significant constraints on the attorney's fees he can recover under $\$ 1988$. In fact, even if the prisoner's injuries were more severe than those of his noninstitutionalized counterpart, the prisoner beaten by the correctional officer may end up recovering substantially lower fees than the nonprisoner beaten by a police officer. ${ }^{272}$

In the second hypothetical example, a police officer beats two people standing together on a corner. The victims' injuries are identical, and both victims file a $\S 1983$ suit against the police officer. But while the first victim is not incarcerated in a correctional facility at the time he files his lawsuit, the second victim is. As a result, the attorney's fees the court awards the prevailing plaintiffs, who sustained the same injuries at the hands of the

271. A comprehensive assessment of the impact of the PLRA's fee restrictions would examine changes, since the PLRA's enactment, in the representation of prisoners by attomeys in cases filed under statutes that can trigger fee awvards under $\$ 1988$. The Administrative Office of the United States Courts ("AO"), the repository of federal-court data, however, does not collect, report, or track this kind of information. Facsimile from Gwendolyn W. Coleman, Technical Information Specialist, Administrative Office of the United States Courts, to Lynn S. Branham (Oct. 3, 2000) (on file with author). Nor does the AO collect even more general data on the number of civil rights cases, including conditions-of-confinement cases, in which attomeys are representing prisoners. Id. Because most state and local inmates file their civil rights claims under 42 U.S.C. $\$ 1983$, a statute that can support a fee award under $\S 1988$, valid inferences about the impact the fee restrictions are having on attomeys' representation of inmates might still be drawn from such general statistics.

272. Because of the $150 \%$ fee cap, a prisoner who was awarded $\$ 5,000$ in damages after being badly bcaten by a correctional officer could recover no more than $\$ 7,500$ in attorney's fees from the defendant. A nonprisoner plaintiff, however, would be under no such constraint. See, e.g., Hyde v. Small, No. 97-3719, 1998 WL 67708, at $* 1$ (7th Cir. 1998) (finding no abuse of discretion when the district court awarded $\$ 11,500$ in attomey's fees in a case in which the plaintiff was awarded $\$ 500$ in damages for an arrest effected without probable cause). 
same malefactor, may differ substantially because of the PLRA's fee restrictions.

From an equal protection standpoint, what is truly perverse is that this fee differential will exist even if, at the time the court enters a final judgment in the cases, the first victim is now confined in a correctional facility and the second victim has been released from prison. The discrepancies in the size of the fee awards will persist because the PLRA's fee restrictions apply "[i]n any action brought by a prisoner" in which attorney's fees can be recovered under $\S 1988 .^{273}$

In a third scenario, suppose that a correctional officer, rather than a police officer, beats two prisoners. Once again, the victims' injuries are identical. The first prisoner is paroled before the statute of limitations runs on his claim, and upon release, he files a $\S 1983$ suit against the correctional officer who beat him. With the end of the limitations period looming, though, the second prisoner must file his $\S 1983$ suit while he is still incarcerated. Only this second prisoner will be subject to the PLRA's fee restrictions. ${ }^{274}$ And he will be subject to these restrictions even if he is released from prison the day after he files his lawsuit.

In the final example of the haphazard line the PLRA has drawn between prevailing parties who recover their full attorney's fees under $\S 1988$ and those who do not, assume that two prisoners confined at the same prison are repeatedly beaten by the same correctional officer. Both prisoners file $\S 1983$ suits against their assailant in which they seek damages and injunctive relief. Correctional officials then transfer one of the prisoners to a different prison while his lawsuit is pending.

The transfer moots the transferred prisoner's claim for injunctive relief because the defendant whom he has sued no longer poses any realistic threat to him. ${ }^{275}$ Since this prisoner will therefore recover only monetary relief, his fee award is subject to the PLRA's $150 \%$ cap. If a jury awards him $\$ 1,000$ in damages, for example, he can recover only $\$ 1,500$ in attorney's fees, a small fraction of the fees actually incurred litigating the case.

By contrast, the prisoner who remains in the prison in which the beatings occurred can recover both damages and injunctive relief. Since the fee cap only applies when "a monetary judgment is awarded,"276 the fee cap most likely will not reduce the total fee award to the $150 \%$ level. ${ }^{277}$

273. 42 U.S.C. $\S 1997$ (d)(1) (Supp. IV 1999) (emphasis added).

274. See the definition of the "prisoner" subject to the PLRA's fee restrictions, supra note 62; see also Doe v. Washington County, 150 F.3d 920, 921, 924 (8th Cir. 1998) (holding that the PLRA's fee restrictions do not apply to a juvenile detainee who was raped, beaten, and "tortured" by other detainees, but who filed his lawsuit after his release from the detention center).

275. See supra text accompanying note 232.

276. 42 U.S.C. $\S 1997 \mathrm{e}(\mathrm{d})(2)$.

277. If it did, prisoners who were awarded injunctive relief only would not be subject to the cap, while those who recovered even more relief, damages, would face a dramatic curtailment in the amount of fees awarded. 
Thus, because of a factor manipulable by correctional officials, the prison where a prisoner-plaintiff is confined, the anount of attorney's fees a court could award the two prisoners in the hypothetical cases could vary significantly, even when the actual fees accrued in the two cases were largely the same.

The analysis in Part III of this Article pinpointed the holes in the arguments that have been asserted in defending the constitutionality of the PLRA's fee cap and hourly-rate restrictions. The preceding examples of the practical effects of the PLRA's fee restrictions further highlight the inanity of basing the amount of the fee recovery under $\S 1988$ on whether the plaintiff happened to be confined in a correctional facility on the date the lawsuit was filed. Conditioning the size of the fee award on this irrelevant fact makes the applicability of the PLRA's fee restrictions contingent on the vagaries of a jurisdiction's policies and procedures governing pretrial release, sentencing, parole release, and the interprison transfer of prisoners. In addition, for many prisoners, whether or not they can escape what can be the draconian effects of the PLRA's fee restrictions will depend on one fact: whether or not the applicable statute of limitations tolls in that particular state while a prospective plaintiff is incarcerated. ${ }^{278}$

The defenders of the PLRA's fee restrictions might, however, respond that this point holds true for many other PLRA provisions, at least soine of whose constitutionality is not in doubt. For example, whether or not an indigent prisoner can avoid having to make the prepayment on the filing fee required by the PLRA ${ }^{279}$ will depend on whetler the prisoner can defer filing the lawsuit until his or her release from prison. ${ }^{280}$ And whether or not the prisoner can wait to file the lawsuit may, in turn, depend on whether the statute of limitations will be tolled during the time the prisoner is confined.

The difference between the PLRA's filing-fee requirement, though, and its restrictions on attorney's fees is that the filing-fee requirement is clearly linked to the legitimate governmental objective of curbing the filing of frivolous lawsuits by inmates. As courts have uniformly recognized, an up-front, out-of-pocket payment requirement will conceivably discourage

278. 42 U.S.C. $\$ 1983$, the statute under which most prisoners' civil rights actions are brought does not define the time by when a $\S 1983$ action must be brought. Nor does any other federal statute delineate a limitations period for $\$ 1983$ suits. Section 1988 states that in the absence of a controlling federal statute, courts are to apply the law in the state where the $\$ 1983$ suit was brought unless application of the state law would conflict with the Constitution or federal law. 42 U.S.C. $\$ 1988$ (a) (1994). Applying this directive, the Supreme Court has held that courts should apply the state statute of limitations governing personal-injury suits to $\$ 1983$ actions. Wilson v. Garcia, 471 U.S. 261, 280 (1985). The Court has also upheld applying in $\$ 1983$ actions a state law that tolls the statute of limitations until an inmate's release from prison. Hardin v. Straub, 490 U.S. 536, 544 (1989).

279. See supra text accompanying note 33 .

280. See Haynes v. Scott, 116 F.3d 137, 140 (5th Cir. 1997) (holding that the prepayment requirement does not apply when an appeal is flled after a prisoner's release from prison); accord Robbins v. Switzer, 104 F.3d 895, 897 (7th Cir. 1997). 
prisoners from filing baseless claims for redress. ${ }^{281}$ In addition, the distinction the filing-fee requirement draws between prisoners and nonprisoners is reasonably connected to this goal. ${ }^{282}$ In part because prisoners have more free time on their hands and because correctional officials provide them with the basic, tangible necessities of life, such as food, shelter, and clothing, it is not irrational to presume that prisoners are more prone than nonprisoners to file frivolous lawsuits. ${ }^{283}$

By contrast, the PLRA's restrictions on attorney's fees invidiously discriminate against prisoners, because the restrictions are not remotely connected to the interest in reducing the filing of frivolous lawsuits or to any other legitimate governmental objective. What is already unconstitutional discrimination against prisoners is simply aggravated by the randomness with which only a select group of prisoners, those confined for shorter periods of time and those in states where the statute of limitations is tolled during any period of incarceration, will be able to limit the adverse effects of this discrimination because of the idiosyncrasies of their state's laws.

\section{$\mathrm{V}$}

ATtORNEY's FeES UNDER $§ 1988$ : THE FRAMEWORK FOR A CONGRESSIONAL POLICY ANALYSIS

If the Supreme Court holds that the PLRA's fee cap and hourly-rate restrictions abridge the requirements of equal protection, Congress will be faced with a policy decision. Should it essentially "let things lie," leaving undisturbed longstanding norms governing the compensation of attorneys under $\S 1988$ under which fee awards are based on the prevailing market rate for the attorney's services? Or should Congress resurrect the PLRA's fee restrictions or adopt other restrictions, but make them applicable to all prevailing parties, both prisoners and nonprisoners, awarded fees under $\S 1988$ ? Either applying existing rules or modified rules to prisoners and nonprisoners alike would satisfy the requirements of equal protection. So the question for Congress is: Which is the preferred course of action from a policy perspective?

In deciding whether or not to change the current rules governing the award of attorney's fees under $\S 1988$, it would behoove Congress to consider why it adopted those rules in the first place. In order to do so, Congress would have to delve into the legislative history of $\S 1988$ 's feeaward provision.

281. See, e.g., Tucker v. Branker, 142 F.3d 1294, 1299-1300 (D.C. Cir. 1998) (listing cases holding that the PLRA's filing-fee provision comports with equal protection).

282. Id.

283. Id. 


\section{A. Congress's Rationales for Enacting the Fee-Award Provision of $\S 1988$}

The legislative history of $\S 1988$ 's fee provision reveals five interrelated premises undergirding that legislation. ${ }^{284}$ The first premise is that many people cannot afford to hire an attorney to represent them on a civil rights claim. ${ }^{285}$ The costs of hitigation can be "staggering," 286 and, because of the nature of civil rights violations, the pecuniary benefits of pursuing a civil rights claim may be low. ${ }^{287}$ Consequently, for individual hitigants, the costs of litigating a civil rights claim typically far outweigh the economic benefits. ${ }^{288}$ Because the damages awarded in civil rights cases are normally so low, the fallback option of retaining counsel by entering into a contingent-fee agreement is, as a practical matter, not an option at all. ${ }^{289}$

The second premise on which $\S 1988$ is grounded is that governmental agencies and private organizations cannot fill this void for civil rights litigants. The Department of Justice does not have the authority to bring suit on behalf of every individual whose civil rights were violated. ${ }^{290}$ And even if it did, neither the Department of Justice nor private entities have the resources to enforce civil rights nationwide. ${ }^{291}$

284. The Supreme Court's decision in Alyeska Pipeline Service Co. v. Wilderness Society, 421 U.S. 240 (1975), was the catalyst for $\$ 1988$ 's enactment. S. REP. No. 94-1011, at 1 (1976), reprinted in 1976 U.S.C.C.A.N. 5908, 5908-09. In that case, the Court held that, absent statutory authorization, courts could no longer, as they had in the past, award attorney's fees to prevailing parties under early civil rights laws, such as 42 U.S.C. $\$ 1983$. Alyeska Pipeline Service Co., 421 U.S. at 269.

285. See, e.g., 121 CoNG. Rec. 26,806 (1975) (statement of Sen. Tunney) ("In the typical case that arises under these statutes the citizen whose rights have been violated has little or no money with which to hire a lawyer, and there is often no damage claim from which an attomey could draw his fee."); 122 CoNG. Rec. S31,832 (1976) (statement of Sen. Hathaway).

286. 122 Cong. Rec. S31,471 (1976) (statement of Sen. Mathias).

287. For example, see the statement of Sen. Tunney, supra note 285.

288. See, e.g., 122 Conc. Rec. 31,472 (1976) (statement of Sen. Kennedy) ("Legal battles to vindicate basic human rights... can be as costly as any other form of litigation, and the costs frequently outrun the economic benefits ultimately obtained by successful litigants.").

289. See, e.g., id. at 33,314 (statement of Sen. Kennedy) ("[C]ivil rights cases-unlike tort or antitrust cases-do not provide the prevailing plaintiff with a large recovery from which he can pay his lawyer.").

290. H.R. REP. No. 94-1558, at 1 (1976).

291. 122 CoNG. REc. 31,472 (statement of Sen. Kennedy) ("Long experience has demonstrated ... that Government enforcement alone cannot accomplish this [compliance with "all the civil rights laws of this country."]); id. at 33,313 (statement of Sen. Tunney) ("Although some of these laws can be enforced by the Justice Department or other Federal agencies, most of the responsibility for enforcement has to rest upon private citizens, who must go to court to prove a violation of the law."); id. at 35,127 (statement of Rep. Holtzman) ("Plaintiffs who suffer discrimination and other infringements of their civil rights are usually not wealthy people. The organizations who have helped them bring their cases are frequently not well financed. The Justice Department does not have the resources to bring suit for every civil rights violation."); id. at 35,128 (statement of Rep. Seiberling) ("The Government obviously does not have the resources to investigate and prosecute all possible violations of the Constitution so a great burden falls directly on the victims to enforce their own rights."). 
The third related premise underlying $\S 1988$ is that the recovery of attorney's fees from the persons or entities who violated an individual's civil rights is the most cost-effective means of enforcing the civil rights laws. ${ }^{292}$ In the absence of such a statute enabling attorneys to recover their costs of representing civil rights plaintiffs, a prohibitively expensive federal bureaucracy would eventually have to be put in place to enforce the civil rights laws. ${ }^{293}$

The fourth tenet embraced by Congress as $\S 1988$ wound its way through the legislative process was that without the fee-award provision im $\S 1988$, the nation's civil rights laws would go largely unenforced. ${ }^{294}$ In the words of members of Congress, unless attorneys who represented prevailing civil rights plaintiffs could recoup their costs, including income foregone representing these plaintiffs, the civil rights laws would be "mere hollow pronouncements."295 The laws would exist "only on paper"296 and be "just a lot of words." 297 Cognizant of the fact that individuals whose rights they had violated would have no effective recourse against them, government officials and others could violate the civil rights of others with relative impunity. ${ }^{298}$

The fifth precept upon which $\S 1988$ is predicated is that enforcement of civil rights is a "highest priority." 299 In enacting $\S 1988$, Congress spurned the notion that there is any such thing as a minor civil right, that

292. Id. at 33,314 (statement of Sen. Abourezk) ("The fee-shifting mechanism has proved a particularly equitable and efficient means of enforcing the law by enlisting private citizens as law enforcement officials. It is a mechanism which increases law enforcement without increasing the Federal budget or bureaucracy.").

293. S. REP. No. 94-1011, at 4 (1976), reprinted in 1976 U.S.C.C.A.N. 5908, 5911 ("[F]ee shifting provisions have been successful in enabling vigorous enforcement of modern civil rights legislation, while at the same time limiting the growth of the enforcement bureaucracy.").

294. S. REP. No. 94-1011, at 5 (1976), reprinted in 1976 U.S.C.C.A.N. 5908, 5913 ("In several hearings held over a period of years, the Committee has found that fee awards are essential if the Federal statutes to which S. 2278 applies are to be fully enforced."); 122 CoNG. REC. 33,313 (1976) (statement of Sen. Tunney) (arguing that without a fee-shifting provision, "the Nation must expect its most basic and fundamental laws to be objectively repealed"); id. at 35,182 (statement of Rep. Seiberling) (" $[\mathrm{A}]$ failure to authorize the awarding of attomeys' fees in civil rights cases will, as a practical matter, repeal the civil rights laws for most Americans.").

295. S. REP. No. 94-1011, at 6 (1976), reprinted in 1976 U.S.C.C.A.N. 5908, 5913; see also 122 CoNG. REC. 31,471 (1976) (statement of Sen. Mathias) ("[R]ights that cannot be enforced through the legal process are valueless."); id. at 31,472 (statement of Sen. Kennedy) ("[W]ithout a provision to permit awards of attomeys' fees to successful parties, the rights secured by those civil rights laws covered by this act are hollow rights indeed.").

296. Id. at 33,313 (statement of Sen. Tunney).

297. Id. at 35,128 (statement of Rep. Seiberling).

298. Id. at 33,313 (statement of Sen. Tunney) ("'If a defendant may feel that the cost of litigation and, particularly, that the financial circumstances of an injured party may mean that the chances of suit being brought, or continued in the face of opposition, will be small, there will be little brake upon deliberate wrongdoing."') (quoting Knight v. Auciello, 453 F.2d 852, 853 (1st Cir. 1972)).

299. S. REP. No. 94-1011, at 3 (1976), reprinted in 1976 U.S.C.C.A.N. 5908, 5910 (quoting Newman v. Piggie Park Enters., Inc., 390 U.S. 400, 402 (1968)). 
fee awards should be reduced because the benefits of certain civil rights lawsuits are largely nonpecuniary. ${ }^{300}$

\section{B. Assessing Congress's Rationales: Right or Wrong?}

The five presuppositions of Congress gleaned from $\S 1988$ 's legislative history provide a starting point for Congress as it determines the best way to equalize the treatment of prisoners and nonprisoners under $\S 1988$. What Congress needs to ask itself is: Are any of these precepts unfounded or no longer true? If the answer to this question is no, then Congress should be hesitant to reduce attorney's fees awarded under $\$ 1988$ below the market value of attorneys' services.

So the questions confronting Congress are: First, can inost people whose civil rights were violated now afford to hire their own attorneys to represent thein in their civil rights lawsuits? If they cannot, has the size of damages awards in civil rights cases increased to the point that attorneys would generally be willing to represent civil rights litigants on a contingent-fee basis im suits for monetary relief?

Second, do government agencies and private organizations now have the resources that would enable thein to represent all or even most individuals whose civil rights were violated? Third, if government agencies and private entities still lack these resources, is Congress willing to allocate the funds needed for the enforceunent of civil rights nationwide?

Fourth, if the fees recoverable under $\S 1988$ were uniformly standardized at the current PLRA rate, would individuals whose civil rights had been violated be able to locate coinpetent counsel to represent them? In other words, are there enough competent attorneys willing to donate their labor on civil rights cases on the condition that they will be compensated at the rate of $\$ 112.50$ an hour if their clients prevail in their lawsuits and at an even further diminished rate in many cases in which the $150 \%$ fee cap applies? Fifth, if not, and government agencies and philanthropical groups cannot fill in the gap left by the paucity of "private attorneys general"301 willing or able to enforce civil rights, how much does it matter if civil rights laws are not enforced? In other words, is the enforcement of civil rights still a "highest priority?" 302

\section{Broadening the Congressional Inquiry}

Apart from reexamining the validity of the premises that prompted Congress to enact $\S 1988$, other information can facilitate Congress's assessment of the continued viability of $\S 1988$ in its present form. In a

300. Id. at 6 ("It is intended that the amount of fees awarded ... not be reduced because the rights involved may be nonpecuniary in nature.").

30I. Id. at 3 .

302. See supra text accompanying note 299. 
broadened inquiry, Congress would also consider whether there are steps, other than tinkering with the $\S 1988$ fee mechanism, that Congress and other policymakers should take to limit the size of fee awards in prisoners' civil rights cases, the focus of the PLRA's fee restrictions.

\section{Data Collection}

Congress enacted the PLRA's fee restrictions in a factual void. At no time was Congress presented with even basic facts regarding the attorney's fees awarded in prisoners' civil rights cases. Those facts should now be collected for Congress's consideration.

Much of the responsibility for collecting the relevant statistical data rests with the Administrative Office of the United States Courts (AO). While the AO currently tabulates statistics on the number of civil cases, broken down by type of case, terminated in federal district courts each year, ${ }^{303}$ the AO disseminates no data on the dispositions in those cases. Consequently, it is not possible at this point to determine such basic information as the following: the number and percentage of civil rights cases in which damages were awarded; the size of those damages awards, including a breakdown of the number and percentage of civil rights plaintiffs awarded damages of a prescribed amount; the number and percentage of civil rights cases in which the plaintiffs were awarded attorney's fees; the size of the fee awards in those cases; and how much of the attorney's fees courts awarded civil rights plaintiffs were incurred to enforce compliance with courts' remedial orders. ${ }^{304}$ Nor is it currently possible to conduct a comparative analysis of the above data in prisoners' versus nonprisoners' civil rights suits. ${ }^{305}$

\section{Measures to Reduce the Incursion of Attorney's Fees in Prisoners' \\ Civil Rights Cases: An Analytical Approach}

The collection of raw, court-based statistics will not alone illumine the steps Congress and other policymakers should take to limit the attorney's fees awarded prisoners in civil rights suits. In order to assess accurately the inport of those statistics, Congress also needs to gain an understanding of the facts giving rise to the awarding of remedial relief, including attorney's fees, to prisoners. In addition, Congress needs to determine whether there are alternative steps, other than changing the fee-award structure under $\S 1988$, that Congress and others can take to limit the size of fee awards in prisoners' civil rights cases.

303. See, e.g., Admin. OfFice of THE U.S. Courts, Judicial Business of the United States Courts: 2000 AnNual Report of the Director, Tables C-4 \& C-4A, at 159-64.

304. Facsimile from Gwendolyn W. Coleman, Technical Information Specialist, Admin. Office of the U.S. Courts, to Lynn S. Branham (Oct. 3, 2000) (on file with author).

305. Id. 
The following information will enable Congress to identify the best means to reduce the attorney's fees accrued in prisoners' civil rights cases as well as other costs that attend prisoner litigation.

\section{a. Deficiencies in Correctional Grievance Processes.}

Prisoners must now seek redress through a prison's grievance process before pursuing a claim in court contesting the legality of the conditions in a correctional facility. ${ }^{306}$ Consequently, many of the conditions-ofconfinement cases in which a prisoner prevails and is awarded attorney's fees under $\S 1988$ represent a failure on the part of correctional officials to avail themselves of the opportunity afforded by the exhaustion-of-remedies requirement to resolve a prisoner's legitimate complaint and avert the filing of a lawsuit.

This failure may stem from problems in the structure of grievance processes, such as limitations on the relief prisoners can obtain through those processes. ${ }^{307}$ Another structural defect in grievance processes may be the lack of an effective mechanism to address prisonwide or systemwide claims, the kinds of claims that, because of their breadth and complexity, typically spawn high fee awards.

The deficiencies in grievance processes that necessitate the filing of lawsuits and the incursion of attorney's fees by prisoners with meritorious claims may not be confined to transparent structural defects. Even if a grievance process is theoretically structured in a way that should lead to the identification and resolution of prisoners' legitimate claims for relief, that process might not work well in practice because of an ingrained institutional bias against providing remedial relief to prisoners.

Whatever the reasons for grievance processes' shortfalls in resolving meritorious claims without the need for litigation, identifying those reasons would be the first step towards eliminating them. Congress should therefore mitiate a fact-finding inquiry, perhaps under the auspices of a task force, to identify ways in which grievance processes can be restructured and revamped to obviate, to the extent possible, the need for prisoners with meritorious claims to have to file lawsuits, lawsuits that will in turn trigger fee awards, in order to obtain redress.

306. See supra text accompanying note 31 .

307. Inmates cannot currently obtain monetary relief through grievance processes for most types of claims. Branham, supra note 261, at 518. The forty-five Departments of Corrections that participated in a survey conducted in March 2000 reported that prisoners either could not obtain monetary relief at all through the grievance process or could obtain such relief for only limited types of claims, such as those seeking recompense for lost or damaged property or miscalculated payments, fees, or charges. Id. In no state could a prisoner procure monetary relief through the grievance process for correctional officers' excessive use of force or unconstitutional conditions at the prison. Id. 


\section{b. The Settlement of Meritorious Claims.}

Prisoners' civil cases, including those in which they are represented by an attorney, are settled less frequently than nonprisoners' cases. ${ }^{308} \mathrm{Ob}-$ viously, if the meritorious claim of a prisoner represented by an attorney is settled early on in the litigation, the attorney's fees the court awards the prisoner will be reduced.

Correctional officials, like other defendants in civil cases, have a tool at their disposal to limit their liability for a plaintiff's attorney's fees: ${ }^{309}$ an offer of judgment tendered under Rule 68 of the Federal Rules of Civil Procedure. The question, though, is whether defendants sued by prisoners are generally utilizing this tool. Or are defendants so averse to providing prisoners with remedial relief, even those with meritorious claims, that they often refrain from tendering an offer of judgment that might bring the litigation to an end?

Part of any fact-finding inquiry initiated by Congress would ascertain the extent to which offers of judgment are underutilized as a mechanism to limit defendants' liability for prisoners' attorney's fees. A comprehensive assessment of the application of Rule 68 in prisoners' cases would be both quantitative and qualitative in nature. The assessment would examine not only the frequency with which defendants tender offers of judgment to prisoners, but also the reasons why some defendants refrain from making such offers in these kinds of cases.

\section{c. The Accrual of Prisoners' Attorney's Fees during the Remedial Stage of Civil Rights Cases.}

As the PLRA moved through Congress, its proponents cited what they considered an endemic problem of correctional facilities operating under court order for prolonged periods of time. ${ }^{310}$ To redress this problem, Congress placed constraints on the scope of injunctive relief in conditionsof-confinement cases and established procedures for the termination of that relief after a prescribed period of time. ${ }^{311}$ What Congress did not do, however, was to ascertain the source of the delay in bringing correctional facilities into compliance with court orders, a requisite to closing a case and ending the accrual of the prisoners' attorney's fees. For example, Congress did not ascertain the extent to which, if at all, the delay was attributable to

308. David Rauma \& Charles P. Sutelan, Analysis of Pro Se Case Filings in Ten U.S. District Courts Yields New Information, 9 FJC Directions 5, 12 (1996) (observing that 18\% of the cases in which prisoners were represented by attorneys settled versus $31 \%$ of those in which nonprisoners were represented by attorneys).

309. See supra text accompanying notes $257-258$.

310. See, e.g., 141 CoNG. REc. S14,419 (1995) (statement of Sen. Abraham) (observing that consent decree entered in Michigan thirteen years earlier "has been a source of continuous litigation and intervention by the court").

311. See supra text accompanying notes $38-42$. 
defendants' resistance to change or legislatures' refusal to appropriate the funds needed to alleviate illegal conditions of confinement. ${ }^{312}$

An obvious way in which to limit the attorney's fees incurred by prisoners while a court's remedial order is being implemented is to execute that order promptly. Consequently, Congress should now do what it should have done before enacting the PLRA, determining, based on facts, not rhetoric, what obstacles have impeded the expeditious enforcement of courts' remedial orders in prisoners' civil rights cases. Ouly then can Congress determine what steps it and other policymakers should take to bring correctional facilities into compliance more promptly with legal requirements and end the accrual of the prisoners' attorney's fees for which the defendants will ultimately be held responsible.

\section{d. Other Mechanisms to Avert and Correct Civil Rights Violations in Correctional Facilities.}

As mentioned earlier when discussing the correction of deficiencies in prison grievance processes, the optimal way to limit liability for prisoners' attorney's fees is to take steps that will obviate the need for litigation to bring correctional facilities into compliance with constitutional and other legal requirements. As part of its endeavor to identify ways to avoid the need for litigation in the correctional context, Congress should examine existing alternatives to litigation, in addition to grievance processes, and their efficacy from the standpoint of averting and rectifying civil rights violations.

One of those alternatives is the correctional accreditation process. Currently, correctional officials can opt to seek accreditation of their facilities by the Commission on Accreditation for Corrections, an offshoot of the American Correctional Association. ${ }^{313}$ Other accrediting bodies accredit discrete parts of correctional institutions, such as their medical facilities. ${ }^{314}$

The effectiveness of accreditation processes in averting civil rights violations has never been assessed by outside researcliers. ${ }^{315}$ Thus, Congress should initiate a study of correctional accreditation processes and other litigation alternatives. ${ }^{316}$ That study would assess the effectiveness of these various alternatives in preventing and correcting the civil rights violations that spawn lawsuits and lead to liability for attorney's fees that

312. For an example of a case in which the court charged that the defendants had engaged in such dilatory litigation tactics, see supra note 255.

313. American Correctional Association, Standards For Adult Correctional INSTITUTIONs, at vii (3d ed. 1990).

314. The National Commission on Correctional Health Care, for example, accredits correctional institutions' medical programs.

315. Telephone Interview with Robert Verdeyen, Director, Standards and Accreditation Division, American Correctional Association (Dec. 7, 2000).

316. For examples of other proactive ways to prevent and remedy violations of prisoners' civil rights without the need for litigation, see BRANHAM, supra note 169, at 56-97. 
Congress, in enacting the PLRA, tried to curtail. In addition, the study should earmark ways in which accreditation processes and other litigation alternatives can be further refined to achieve those objectives.

\section{VI \\ CONCLUSION}

Adjudging the constitutionality of the PLRA's $150 \%$ fee cap and hourly-rate restrictions would present a test for the Supreme Court. The Court has insisted in the past that the rational basis test is not "toothless"317 and that it provides meaningful protection from the erratic and disparate treatment that are the hallmarks of invidious discrimination. However, the fee restrictions involve prisoners, who have traditionally been maligned and scorned. So the Court may be tempted to engage in creative thinking when assessing the constitutionality of the fee restrictions, imagining legitinuate objectives that supposedly justify making it more difficult for prisoners than nonprisoners to enforce their civil rights. Yet if the Supreme Court were to uphold the constitutionality of the PLRA's fee restrictions in the face of an equal protection challenge, the Court's avowed fealty to equal protection principles would be revealed for what it is: lip service.

The PLRA's fee restrictions also presented, and still present, a test for Congress. The questions the restrictions raised and continue to raise for Congress are: Will it ascertain the facts before enacting or retaining legislation that has the potential to impair severely the enforcement of civil rights laws? Or will it reflexively adopt or retain such legislation, skirting the channels established to unveil constitutional or policy-based problems with the legislation?

Many people would be diffldent about how Congress answers these questions in the prisoner context; few people become exercised about prisoners' inability to enforce their constitutional rights. However, they should for at least three reasons. First, we profess to be "a government of laws, not of men." 318 Shutting the courthouse door for all practical purposes on sone prisoners whose civil rights were violated is antithetical to this governing principle. Second, it is dangerous. By, in effect, telling prisoners, "You are not as worthy of the law's protection," that whether or not they are beaten, deprived of medical care, or forbidden from worshipping is of no consequence to us, we are telling them that we consider them subhumans. And be assured, they will live down to our lowest expectations. Denied legal means to vindicate their civil rights, they may, eventually, resort to destructive and illegal means, such as rioting, to air their grievances. ${ }^{319}$ And

317. Matthews v. Lucas, 427 U.S. 495,510 (1976).

318. Marbury v. Madison, 5 U.S. (1 Cranch) 137, 163 (1803).

319. Cf. Holman v. Hilton, 542 F. Supp. 913, 921 n.15 (D.N.J. 1982) (noting that "it is very obvious that the availability of redress in the federal courts provides an outlet for tensions in the 
they will take the lessons they have learned while in prison, that while they were confined for violating the law, government officials can violate the law with relative impunity, and the resentment those lessons engender back with them onto the streets.

Finally, for those people unmoved by the inoral and practical considerations that make a compelling case for the enforcement of prisoners' limited civil rights, they should remember that freedom is typically lost not in one fell swoop, but in increments. While today "only" the ability of prisoners to enforce their civil rights is at stake, tomorrow new restrictions on the recovery of attorney's fees under $\S 1988$ may affect the ability of all but the rich to enforce their civil rights.

The PLRA's fee restrictions have opened what may prove to be a Pandora's box. It remains to be seen whether Congress, with or without prodding from the Supreme Court, has the discernment to shut it. 
